\title{
東京市內街路照明の實況に就て
}

\author{
正會員 堀 岡 正 家 \\ 山崎 源 貞 \\ （遞信省電州試驗所）

\section{On the street Lighting of Tokyo.} \\ M. Horioka Member \\ By \\ M. Yamasaki
}

(Electrotechnical Laboratory, Ministry of Communication.)

\section{內 容 梗 摡}

我東京市に於て現在道路汇施設されて居る街路照明即ち震災後殘存せる街路照明設借の調查照度の貫側等 を行ひ其結果を內外の代表的街路照明と比較し現在東京於に於ける街路照明設供が組蟣的に統一せざる比校 的小規模のもの多く又照度も概して低い事を確證し照度其他の標準を示し新都市建設の途にある我東京市の 街路の新設に際し即か參考に供せんとす。

目次

一、總論

二、测定䇢所の概況及び湘定方法

三、澌定結果

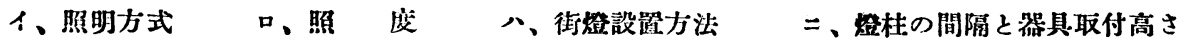

ホ、使用光源亚に街路器具の種類及び其配光

四、震炎㨁後上り最近に至る東京市街路照明に就て

五、內外の代表的街路照明と現在飞於る東京市の街路照明

六、結諭

\section{SYNOPSIS}

This report is the desciption of the street lighting of Tokyo and its most part is the measured data on about all the street lighting systems of Tokyo relived from the earthquake of 1923 .

Many disbribution curves taken by Macbeth illuminometer. the photographs of lighting standards etc, are given.

一、總論

大正十二年九月一日の震火竾に引續さ暗垚の裡に過されれる數日間の安寧秩序の 維持甚た困難にして民心の不安極度に達してるの事筫に鑑み屋外の照明が公安に對 
して如何なる深さ關係を有するかは萬人の等しく鉛記しんる處なる。米國に於ては 街路照明と犯罪或は交通事故等に關し貴重なる統計的調查の發表せらるるもの手邦 に於ては著者の知る範圍內に於て未だ其類なさが如し。我東京市に於て子大震災後 新都市の建設には其類の統計的調査は貴重なる參考資料えるべく。本調查は斯の如 〕街路照明と公安との間の具體的統計を得ん事を終局の目的としんるも調查の範園 多岐廣汎に亘 b到底急速の結果を擧げ得べくるあらず。依つて取敢へず是か調查の 第一步として大正十二年十月初旬より約一ケ月の間に於て賞時震火災を乭れて殘 存せる東京市內各所に就て宾地踏查せる街路照叨施設の實況と其後今日に至る迄

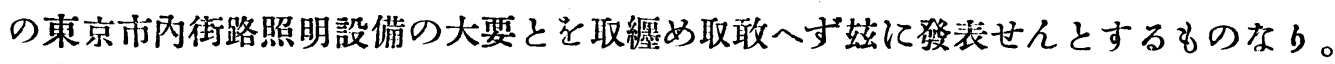

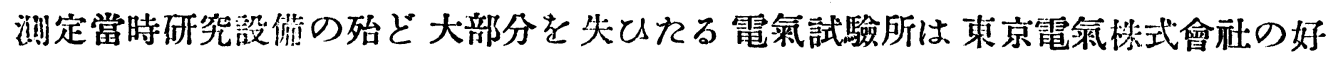
意によb必要なる測定器具を手にする事を得且當時の會社石川照明課長、太田工學 士を初め杉山彌一，熊谷忠雄、清水大壮の墸氏は震災後合日淺く深夜の測定を困難 とする幾多の事情ありしに係らず賽地踏査に多大なる隹援を與へられれるは威謝に

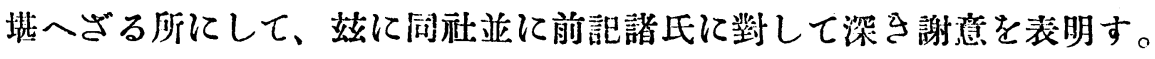

大正十二年九月一日以前に於ける東京市內街路照吸の施設せられれる個所は大路 次に示す如し。

震災後殘存せる筐所（大略）

芝 區 三光圾下 三田綱町 ”三田四國町 南传久間町

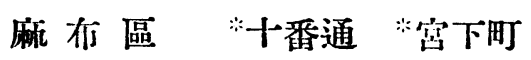

赤 坂 區 *青山南町 *棐山北町 *明治种宮參道

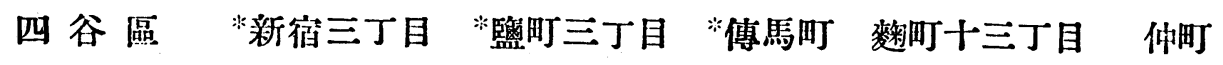

麴 町區＼cjkstart粼町八丁目”東京驛前 三菱銀行前

牛込區“通寺町 "肴町 "神樂坂 "饭田祜附近

$\overrightarrow{0}$ 本 鄉 區白山 高等學校前

涉此 谷 町澁谷町電車近 *下廣尾通 *新橋通

（*は本調查に於て測定せる個所なb）

(1) Earl A. Anderson; " Illumination and Traffic Accidents" I. I. S. 1921 and "Strect Lighting and Public Safty" Bul of National Lamp works May 5. 1922.

(2) Report of National Electric Light Association 1924 pp. 588-594. 
震災によb焙失せる簀所

茫區田村町・南传久間町

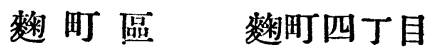

京 橋 區 銀座通 京橋通 築地精飬軒前 叨石町 剛崎町

新富座前

日本橋區人形町 日本橋通通三丁目附近 僙山町

神田區今川小路 表神保町

下 谷 區廣小路交叉點附近 不忍池附近

本 所區向島堤 柳島附近

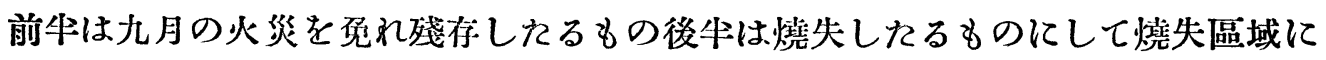
於りる街路照明施設の區域等の詳細に亘りては今全く調查の資料を有せず。唯東京 市內街路照明施設の牛數以上を燒失してるものと漠じて誤なかるべし。

\section{二、測定筒所の概況、測定方法}

本調沓に於て測定せる各施設筒所は上記の表中*印を附訅しれるものにして當時 残存せる䇢所の大半を網羅せり。各所の一般概況としては大震災後日省棧さに係ら ず各燈柱上に電球の做如せるものは殆んど見當らず。唯グローブの破壊し又は缺如

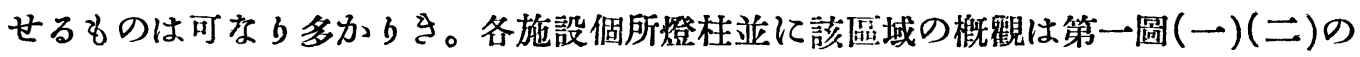
寫且圖(代表的のものを示す)に於て明なるべし。

各簀所に就さ測定方法を二大別として一は配光曲線を得んが爲の精密なる测定、 他は該施設䇢所の全本均照度を得ん爲の略測定とし前者はマクベス照明計をすつて 6 乃至 25 呎每の路面上各點の照度を、後者は呎燭計を用とSて各街路幅を四等分す る中央及兩侧線の三線に沿と地上約 2.5 吹の照度を約 50 吹每に測定せ b。精密 測定に於ては該照明設備施設箇所に於て街路照明登以外よbの影響極めて少さ場所 を撰定して測定を行とれb。本調查に於ける斯の如さ場所に於て他の光源よりの影 響は後に計算上よbも確めてるが如く殆ど無視して然るべき程度なり。少一測定每 に街登電壓を測定し凡て之を規定電壓值に於りる燭光に換算せり。呎燭計をるつて 測定せる時は測定者直立のむ〉地上 2.5 呎の照度を測定せ b。本方法は其の 結果 極めて粗策なるを免れずと踓も街路照明設備の全區城の照度を各所につす概括的に 比較する事を得べし。呎燭計による測定は各照明簀所の殆ど全區域に就て行でれる も街燈以外の光源よbの影響甚だ多す事を記憶せざるべからず。少街路照明施設區 


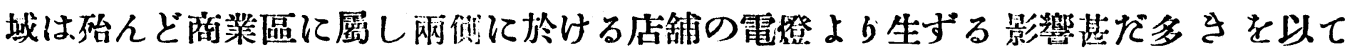
店舖の閉銷後に於ける深夜に於て測定せb。

\section{三、測定結果}

測定の結果は之を测定線に沿へる照度曲線と均等照度曲線とに分ち第一圖乃至第 七圖（筫測箇所中代表的のるのを示す）に揭げれる。

第一表は呎烛計に依る結果なる。圖中燈柱の位置とは燈柱上に設搹せられれる全 電球の幾何學的中心位置を示するのなり。今筫測より得れる結果中よb下記の譛要 項に付さ記述せん。

1、照明方式

口、照度

八、街路設置方法

二、間隔と取付高さ

ホ、光源街路器具の種類及び其の配光

1、照时方式

望測箇所は商業街(東京驛を除く)にして主として均等照明方式が探用されて居る、 街路照明に於ては屋內に於ける如さ高さ均一度を必要とせず多くの場合最高照度と 最低照度との比が $\frac{1}{10}$ 乃至 $\frac{1}{15}$ 位の範圍內にある時は均等照明と呼せらる賀測筒所に 就て見るに第二及第三表及び第二圖乃至第七圖に示す如くにして均等照明に屬する 部分は全部の 3 分の 2 を占ひ。

口、照度

實測せる箇所の店舖の殆ど全部は開放的なるが故に街路照明設備のみよbの照度 を测定せんとし閉店後に於て測定を行ひたb。實測及び計算よb得れる照度及其曲 線置は第二圖乃至第四圖及第八圖乃至第十圖並に第一乃至第三表に示す、第一表は 吹瀷計に於て測定せるものにして照度の大臵を示し一街路の本均照度を示すものな b即街路照明設備の途切れれる小部分をる含し事と測定者の陰とによb本均水本 面照度は 0.04 乃至 0.1 呎燭なる可な $b$ 低导價を示せb。然し我國の商店は大部分か; 開放的であ b、且道愊子猍小なる故に店內燈が街路の補助照明登として役立つ場合 多く道路の狹さ所にては上訅の值の 2 乃至 3 倍以上に達する事も少からず。街路照 


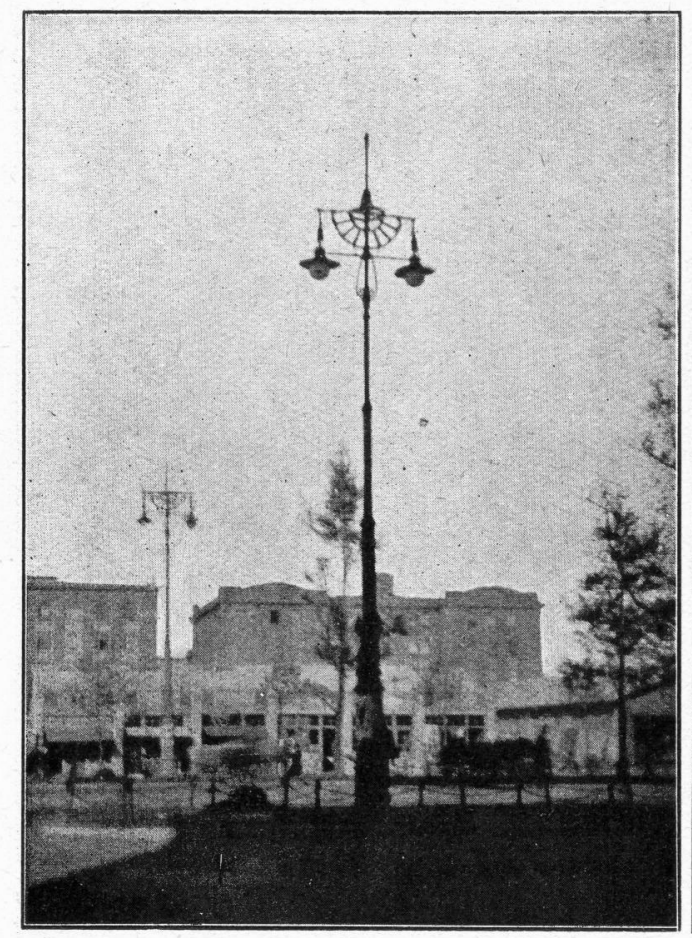

（東京譆前)

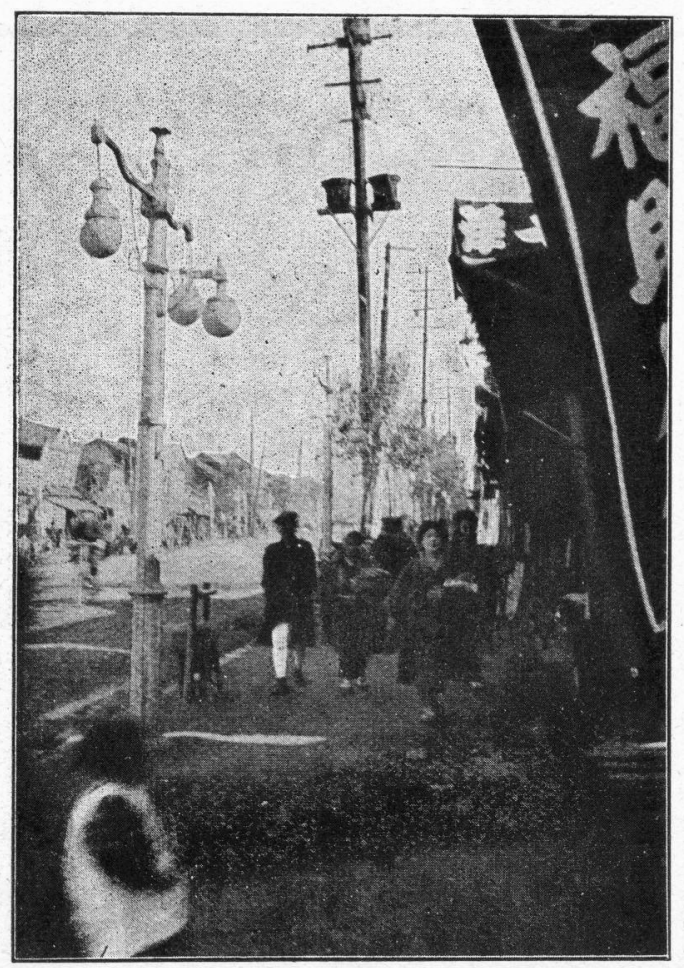

(四谷䇶町)

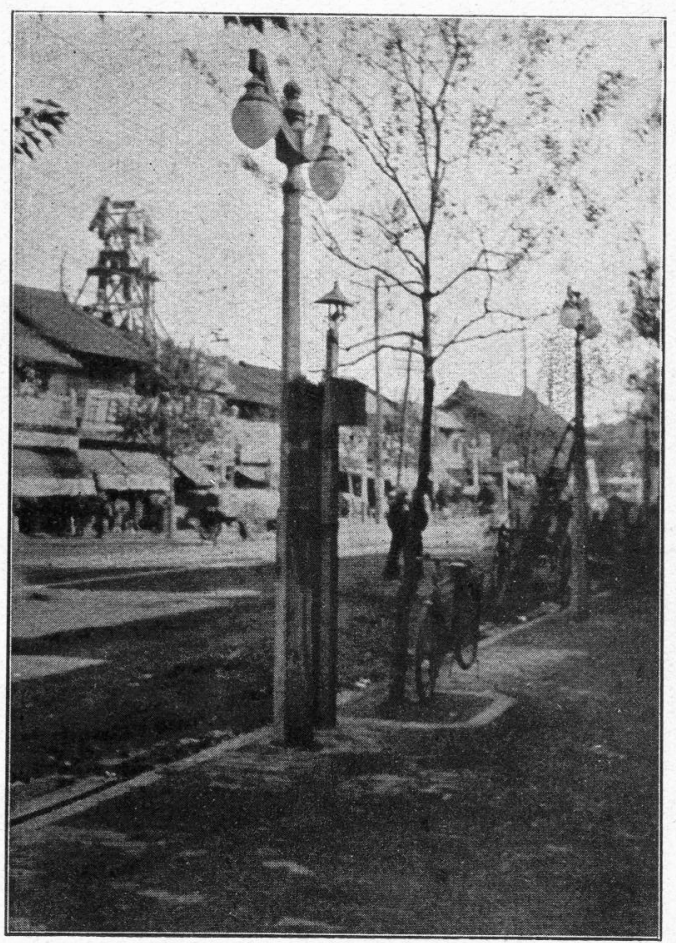

(四谷䁛 町)

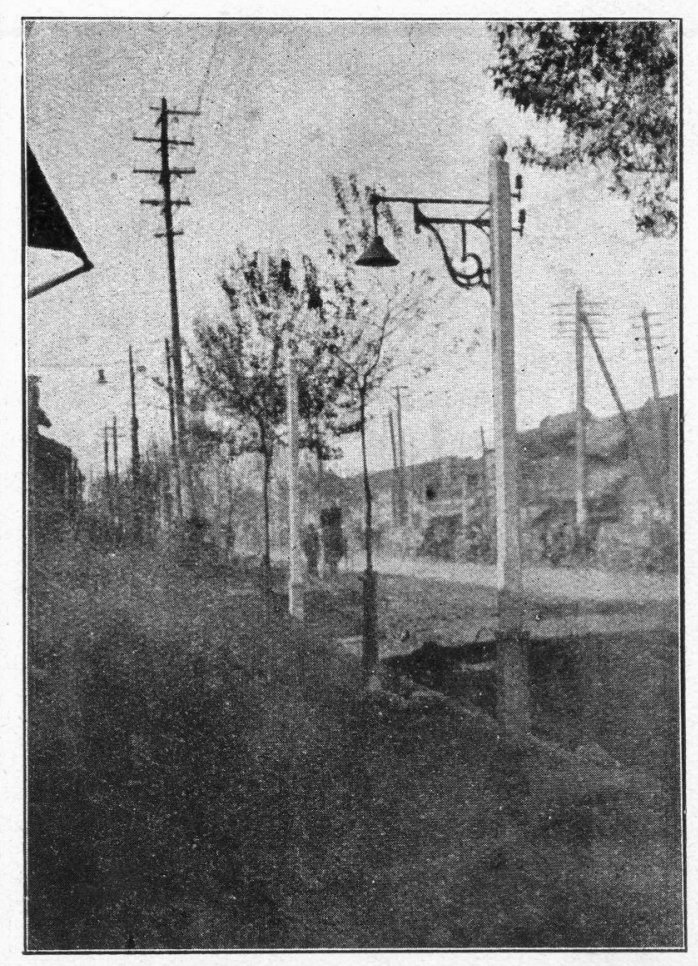

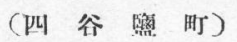




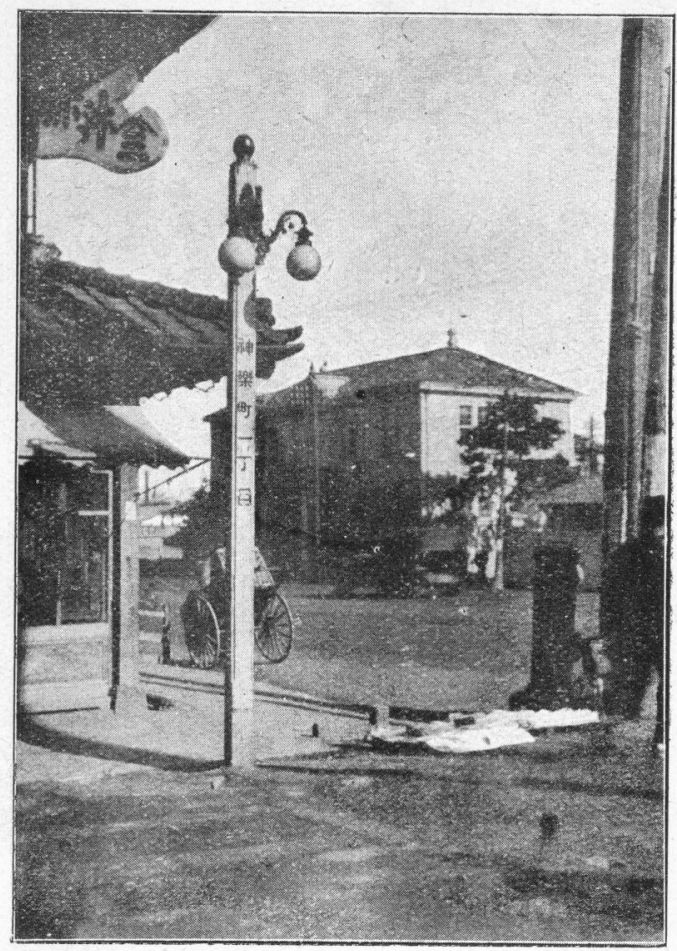

(生达神樂仮通)

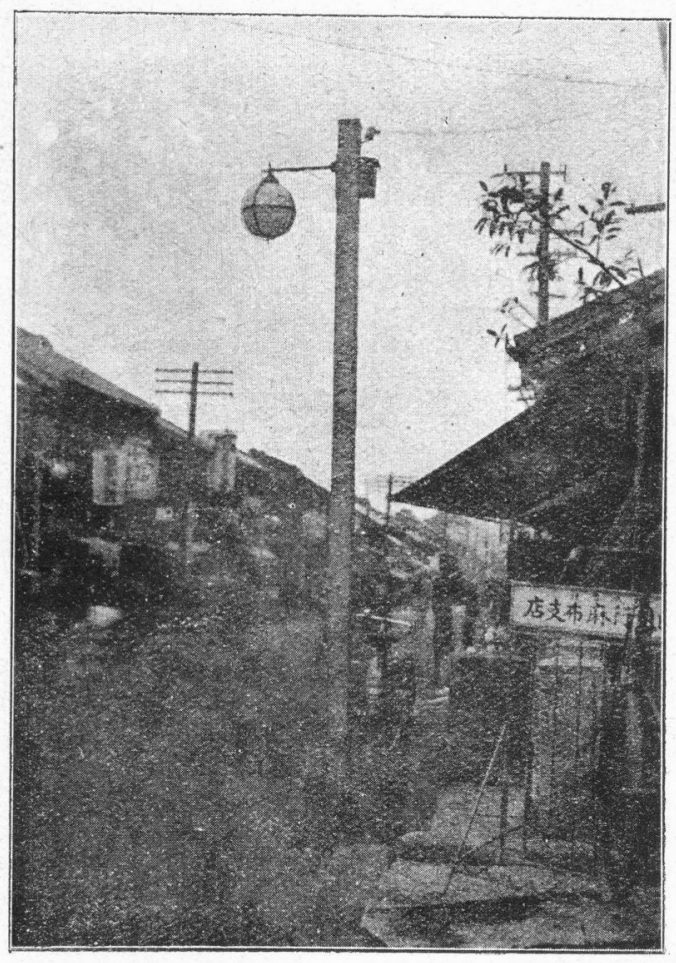

(麻有十番通)

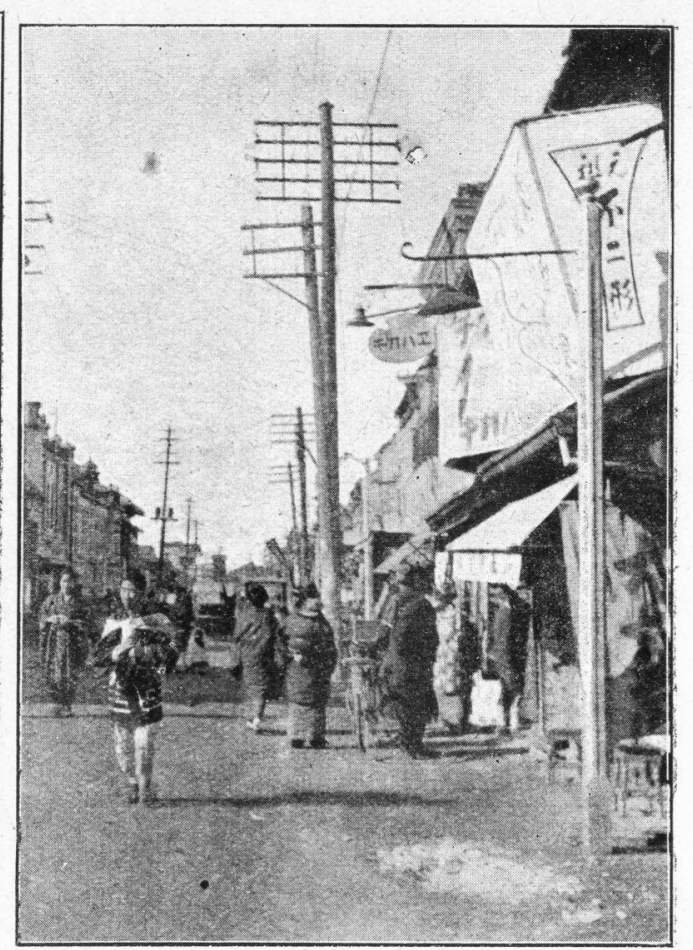

(牛达神樂坟通)

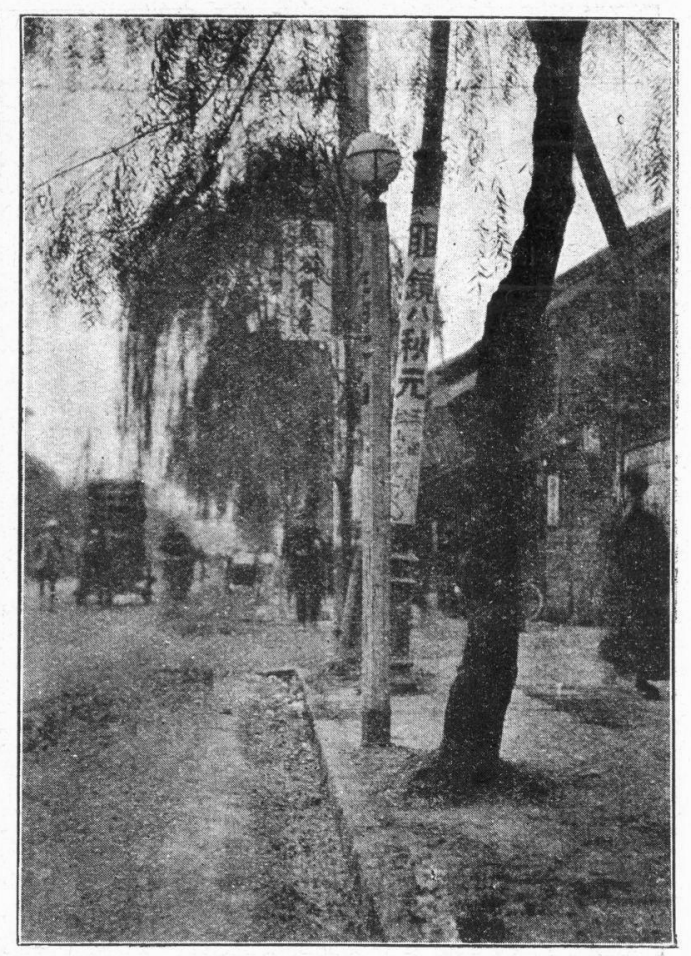

(三田通) 
第

東京市內街路照明表

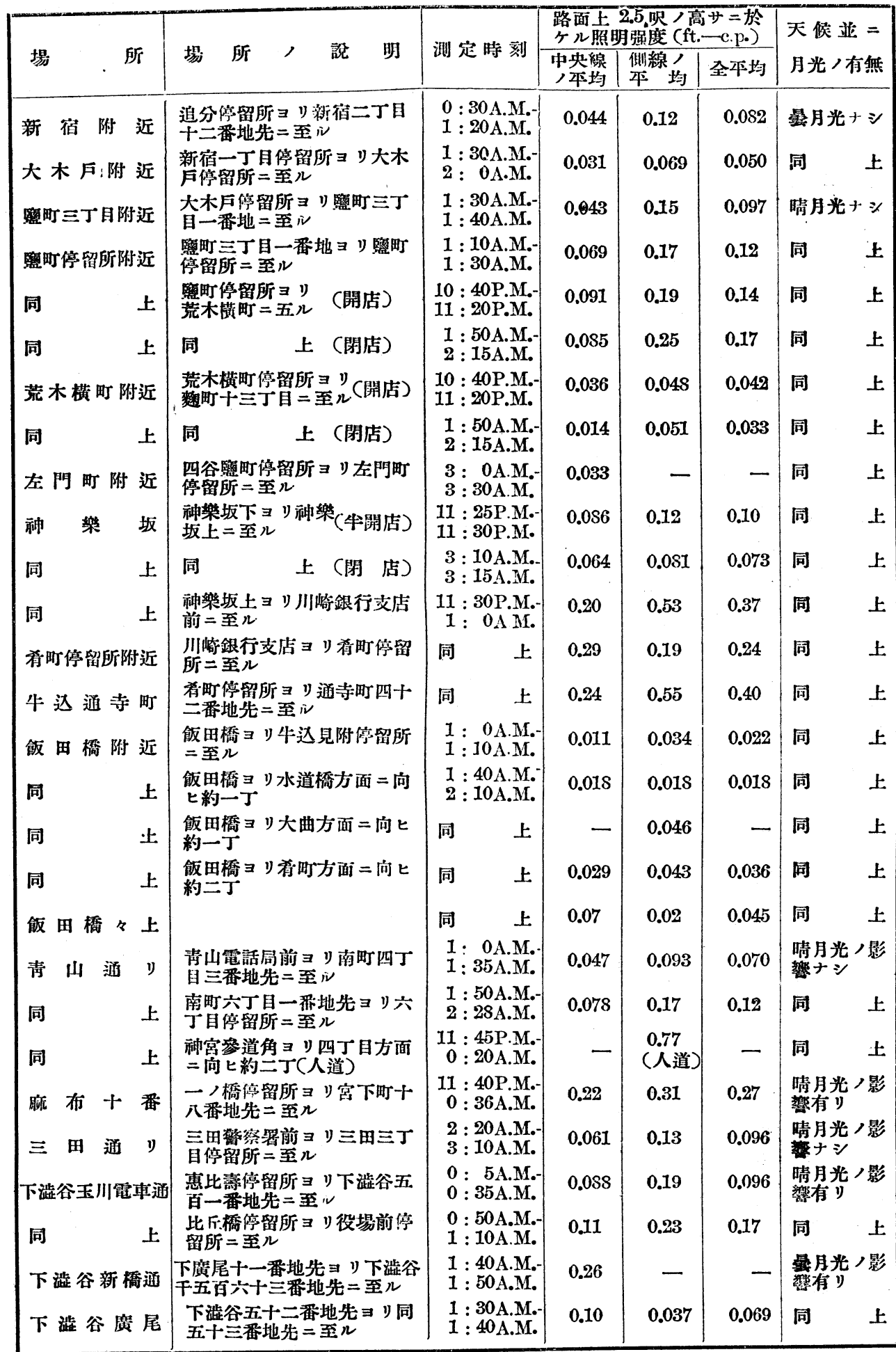

表

测定器具: 吹 㯰 計

测定年月：大正十二年十一月 


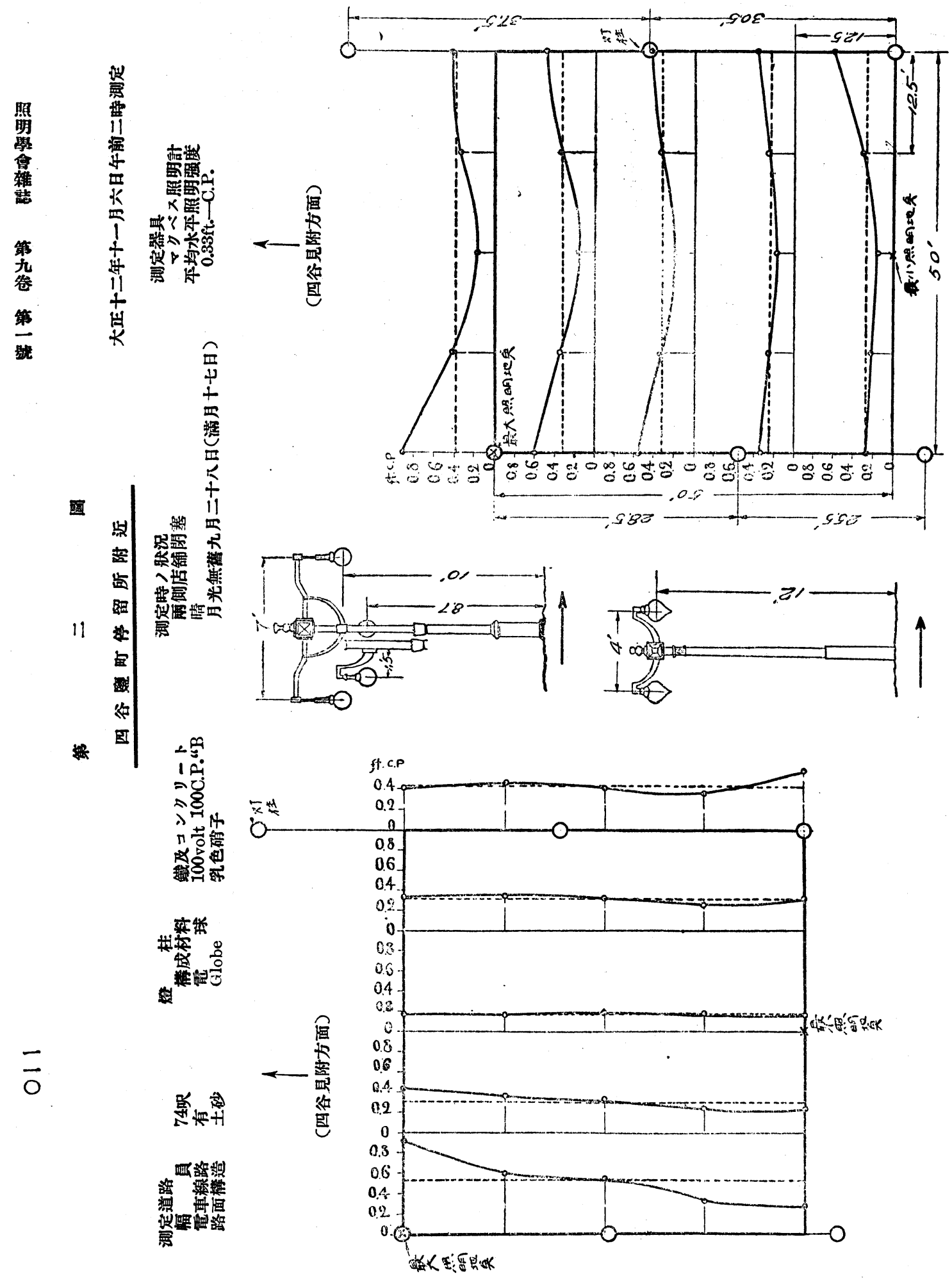




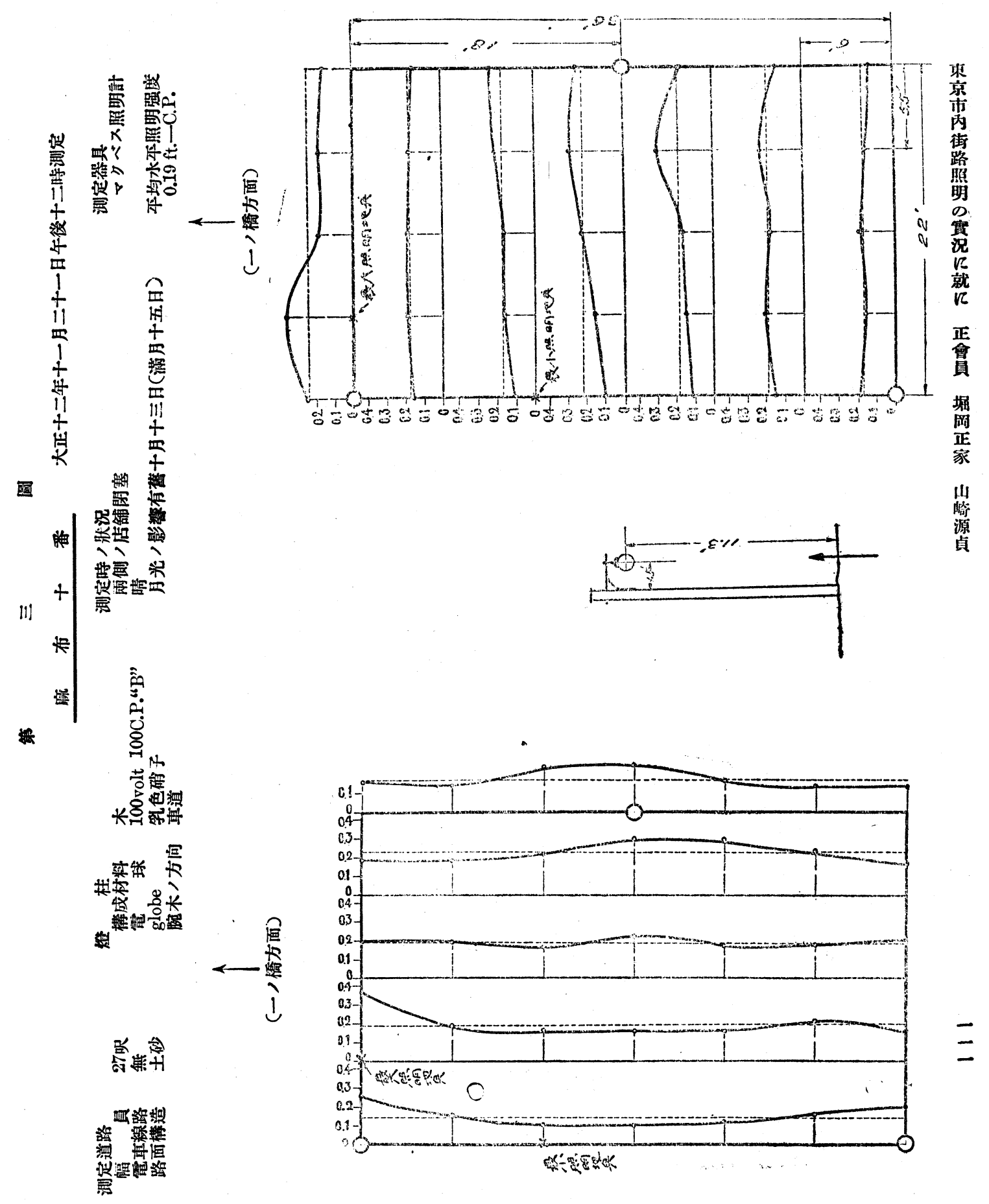




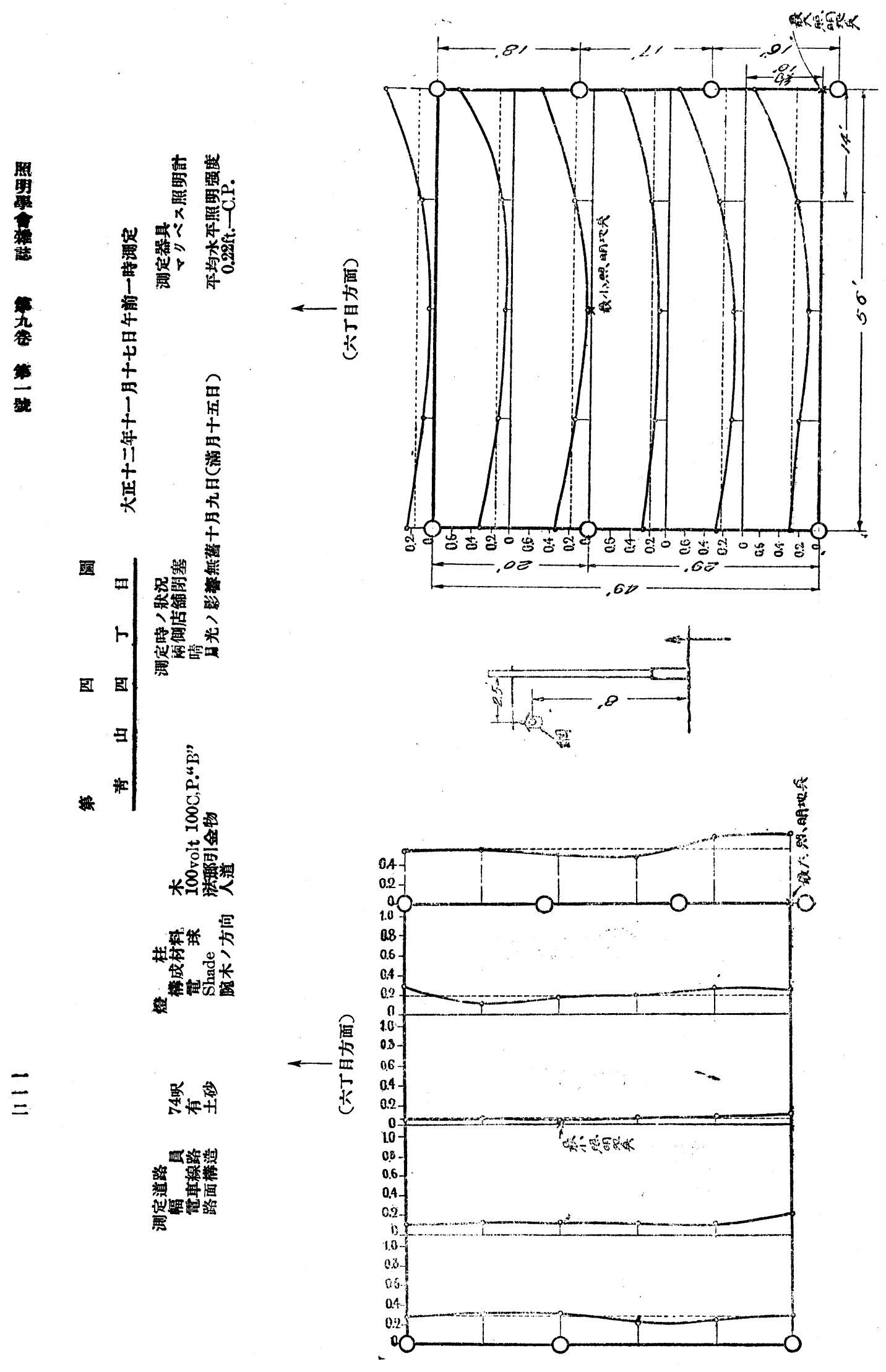


第五圖

四谷留町停留所附近

(均等照度曲線圆)

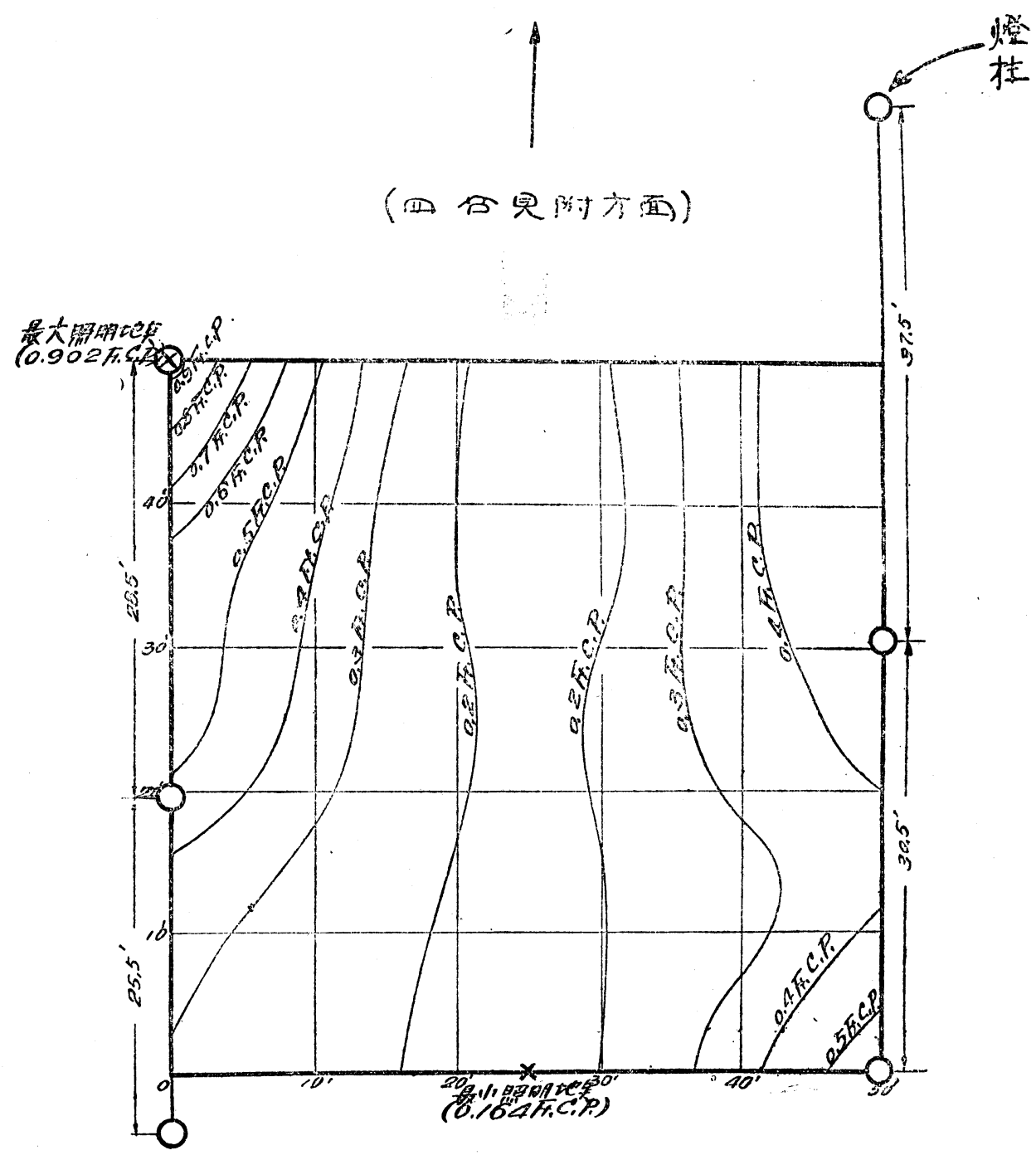




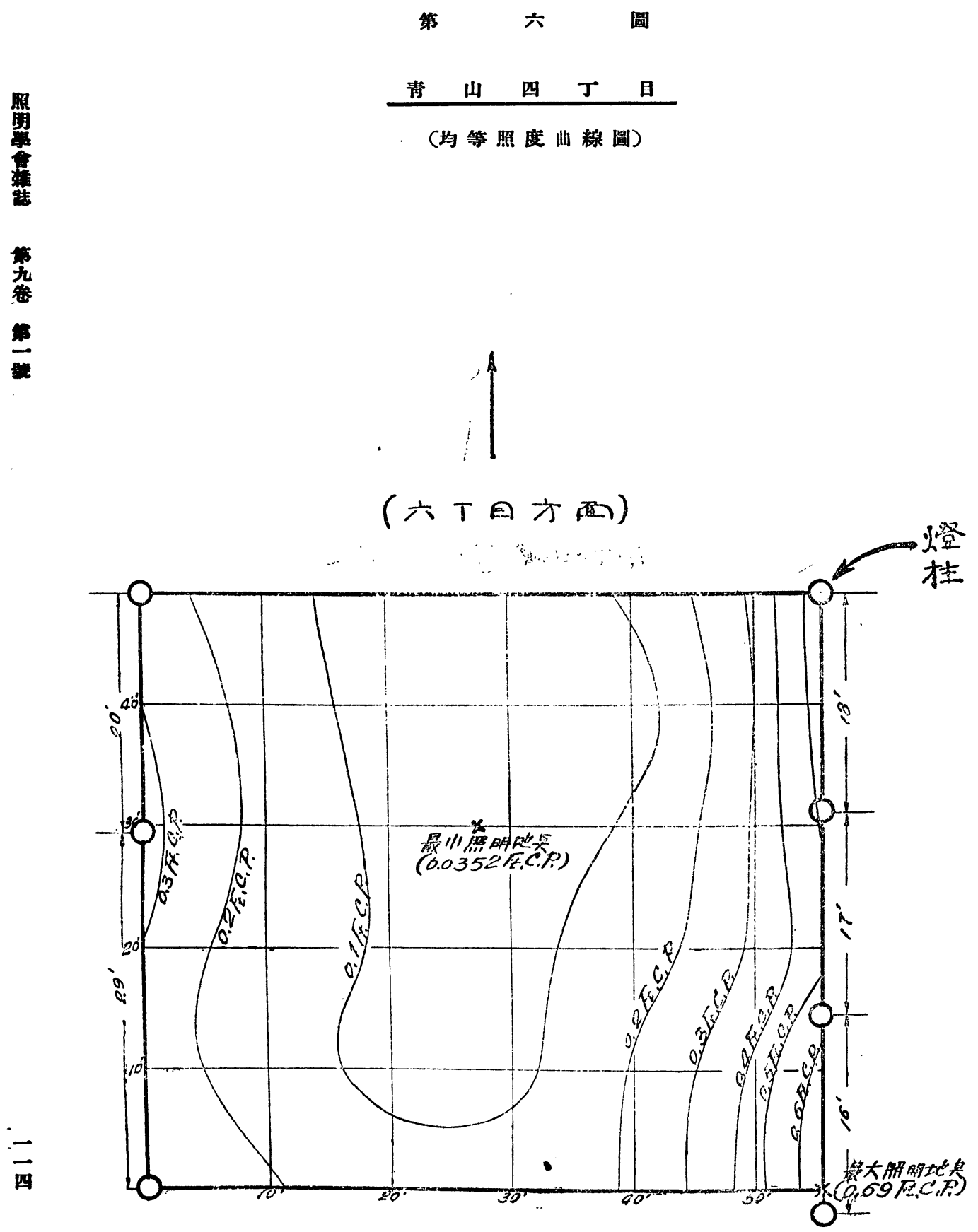




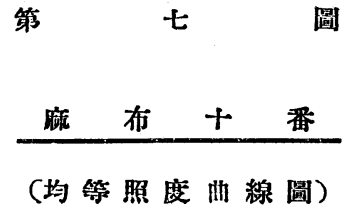

麻布十番

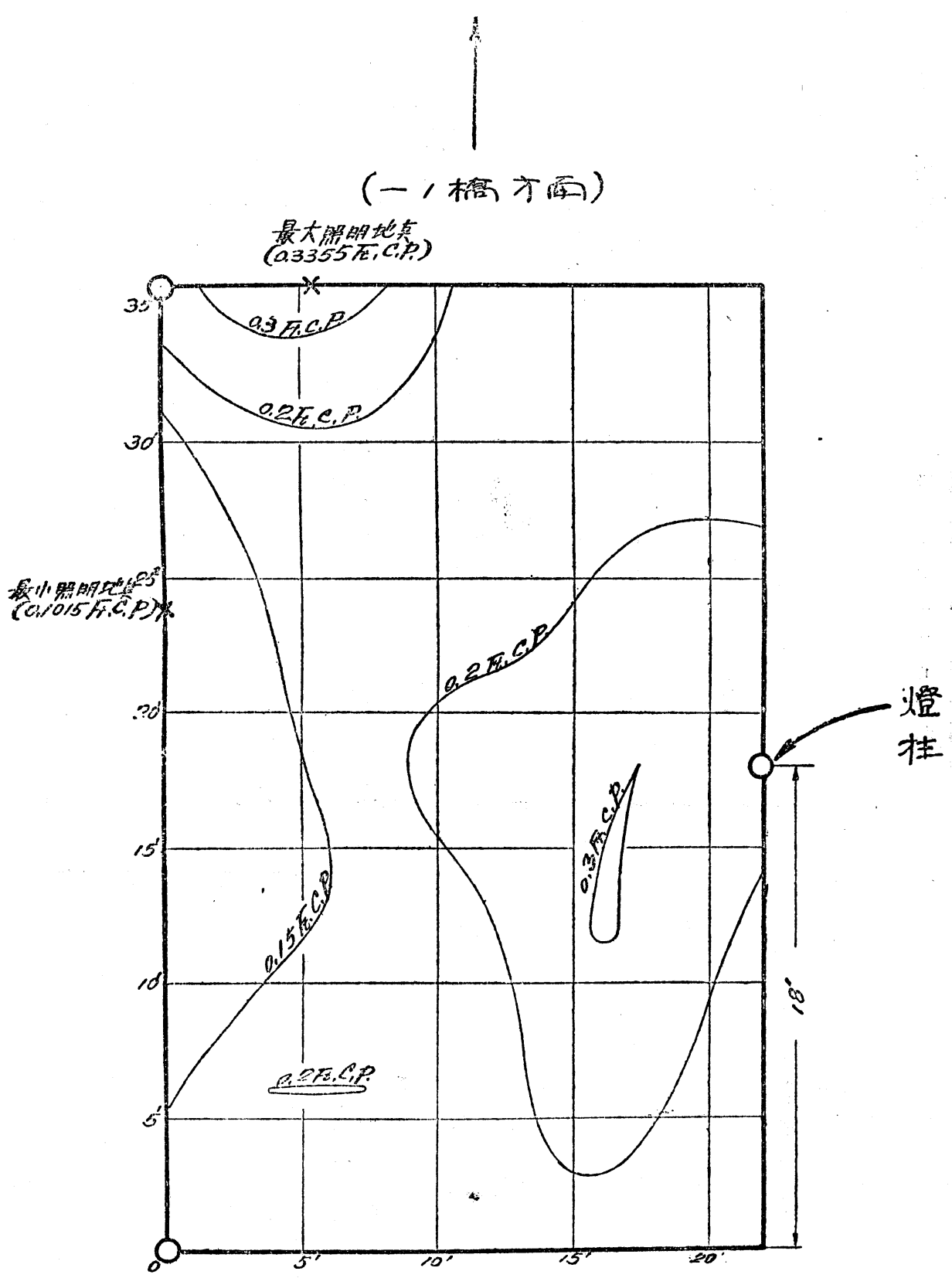

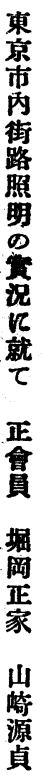

燈 挂 

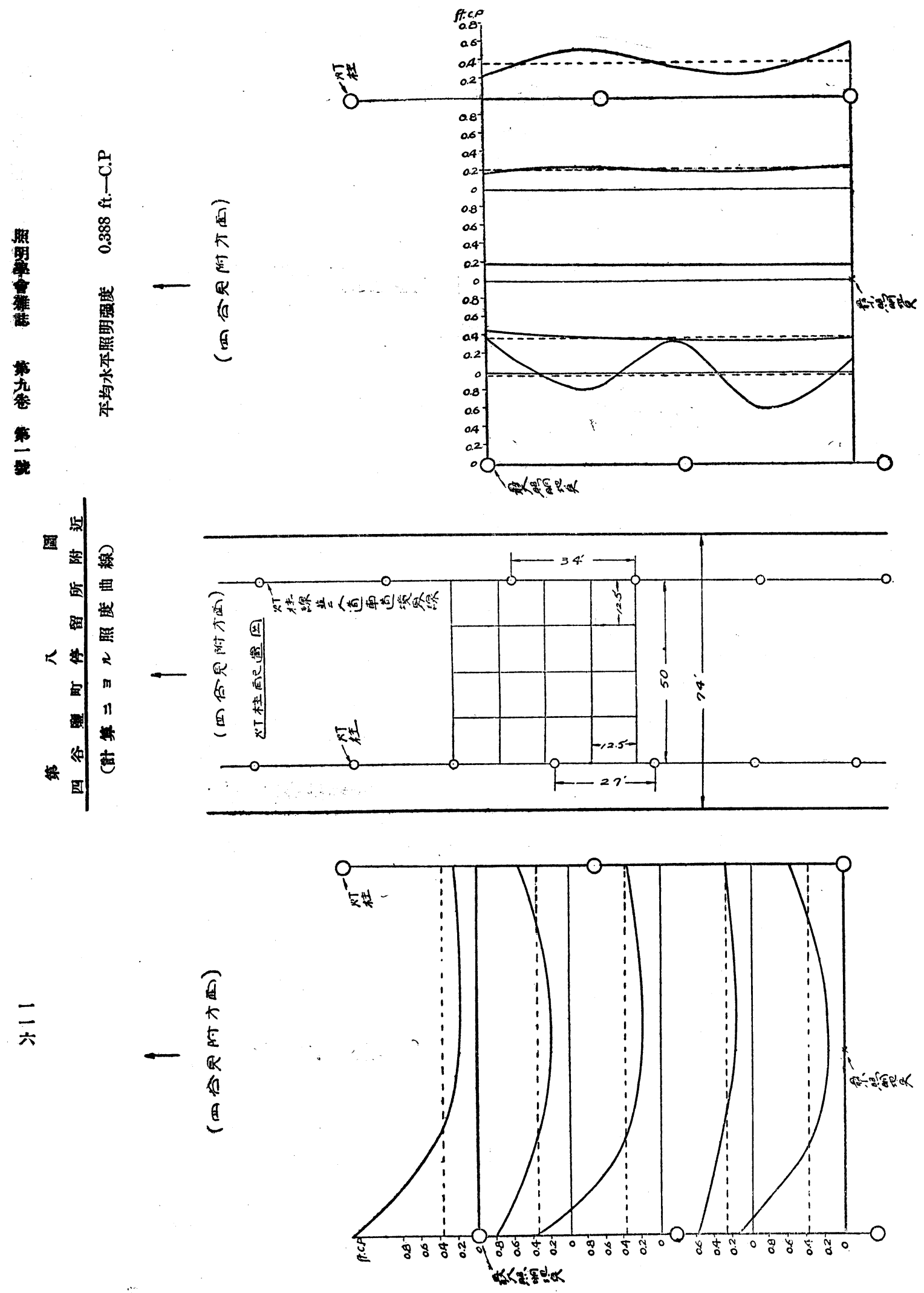


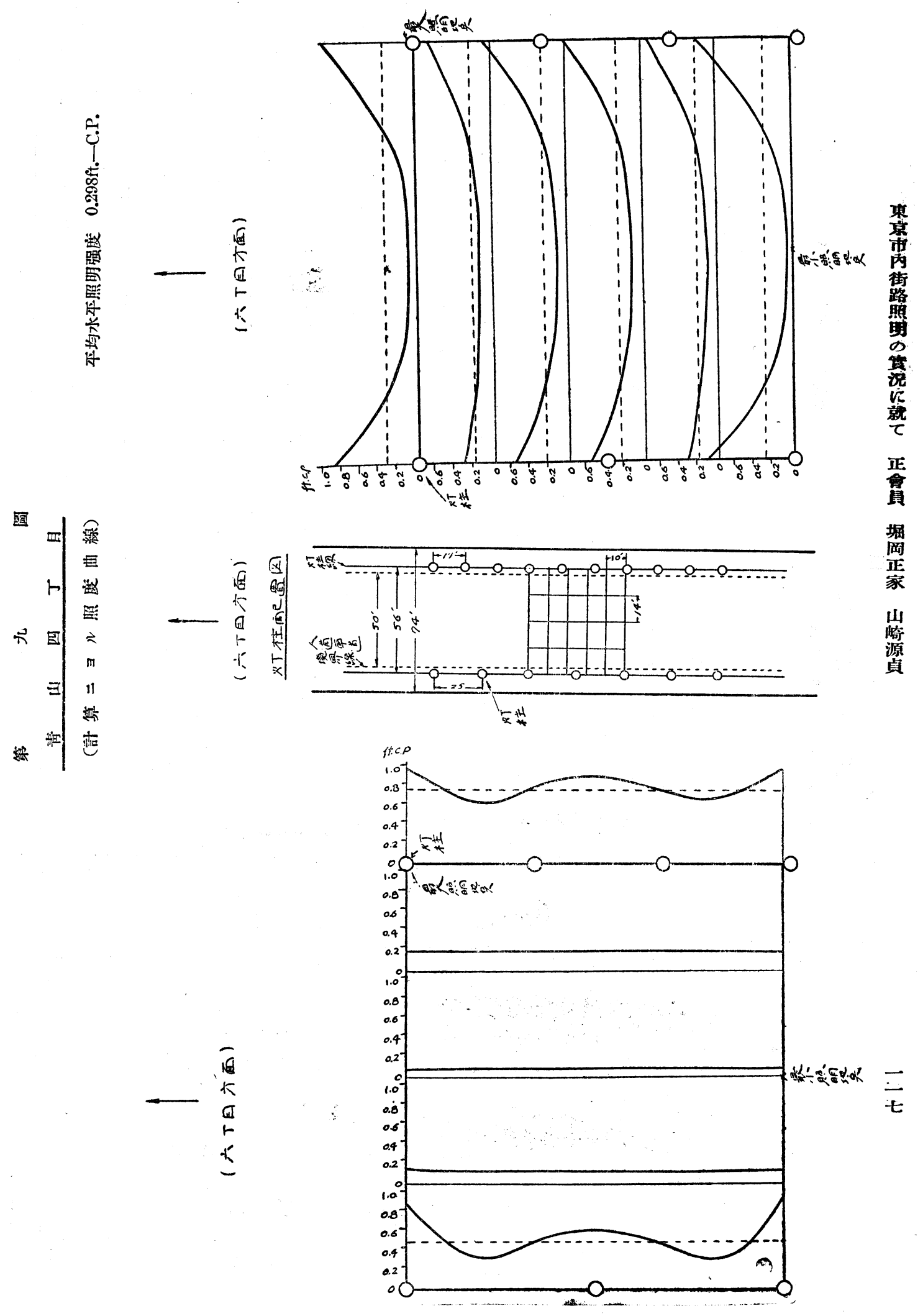



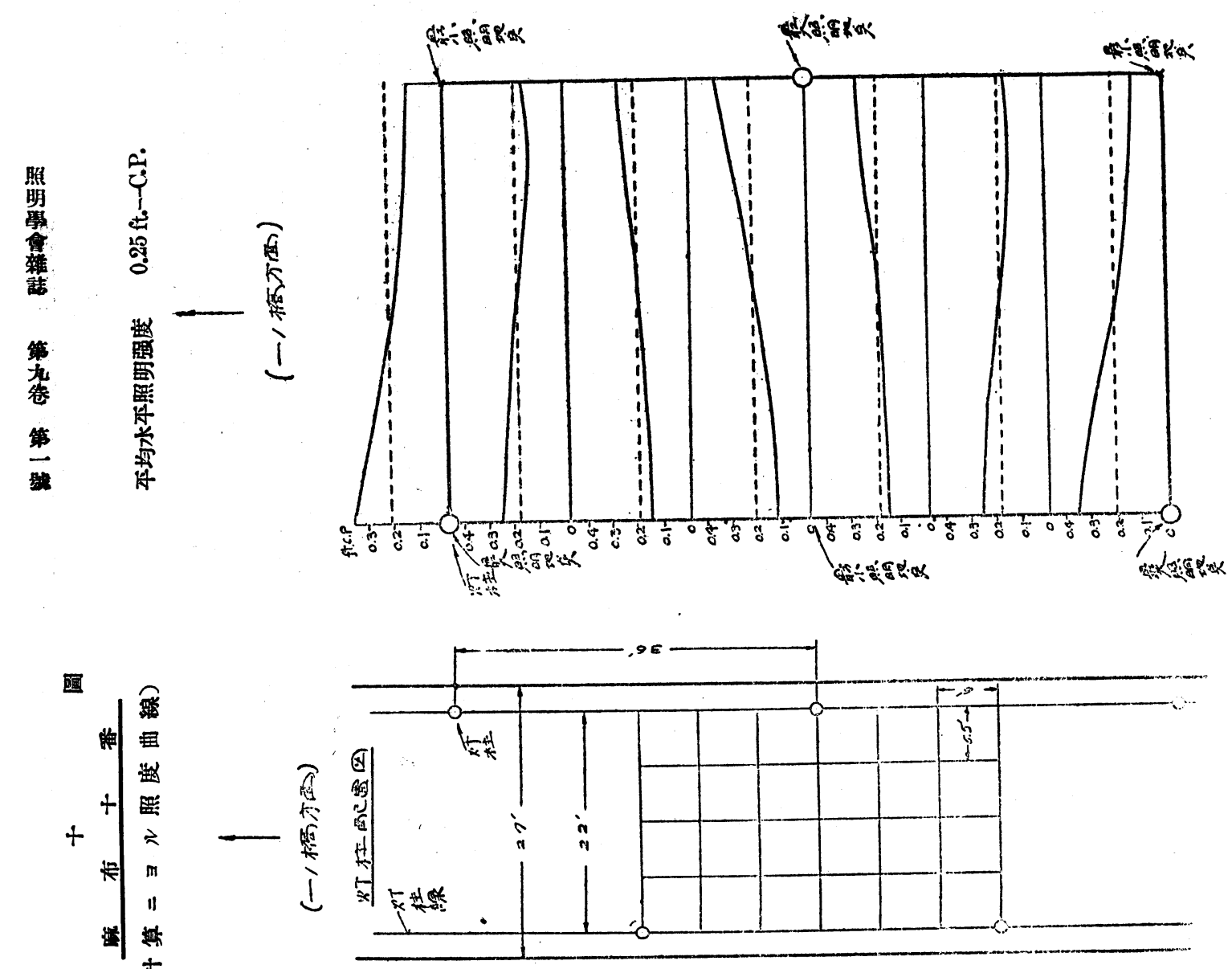

地

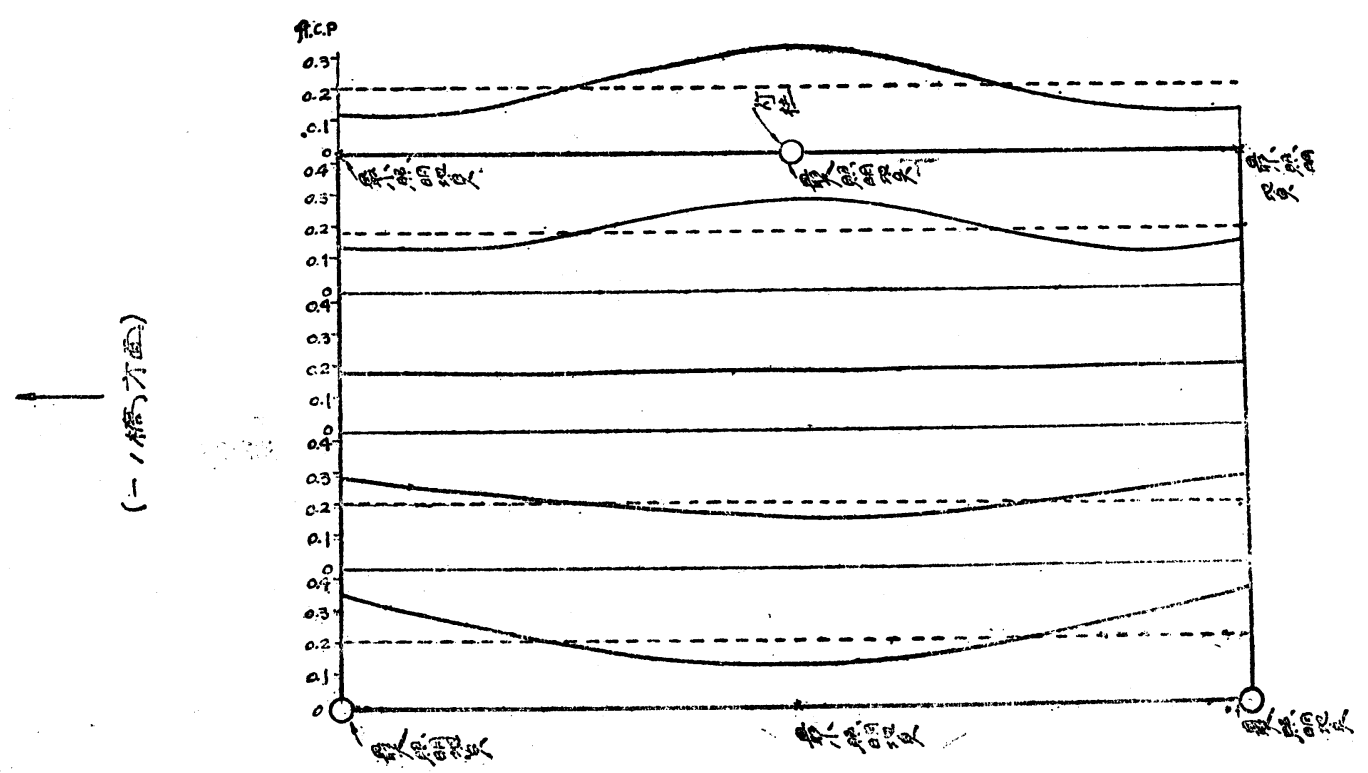




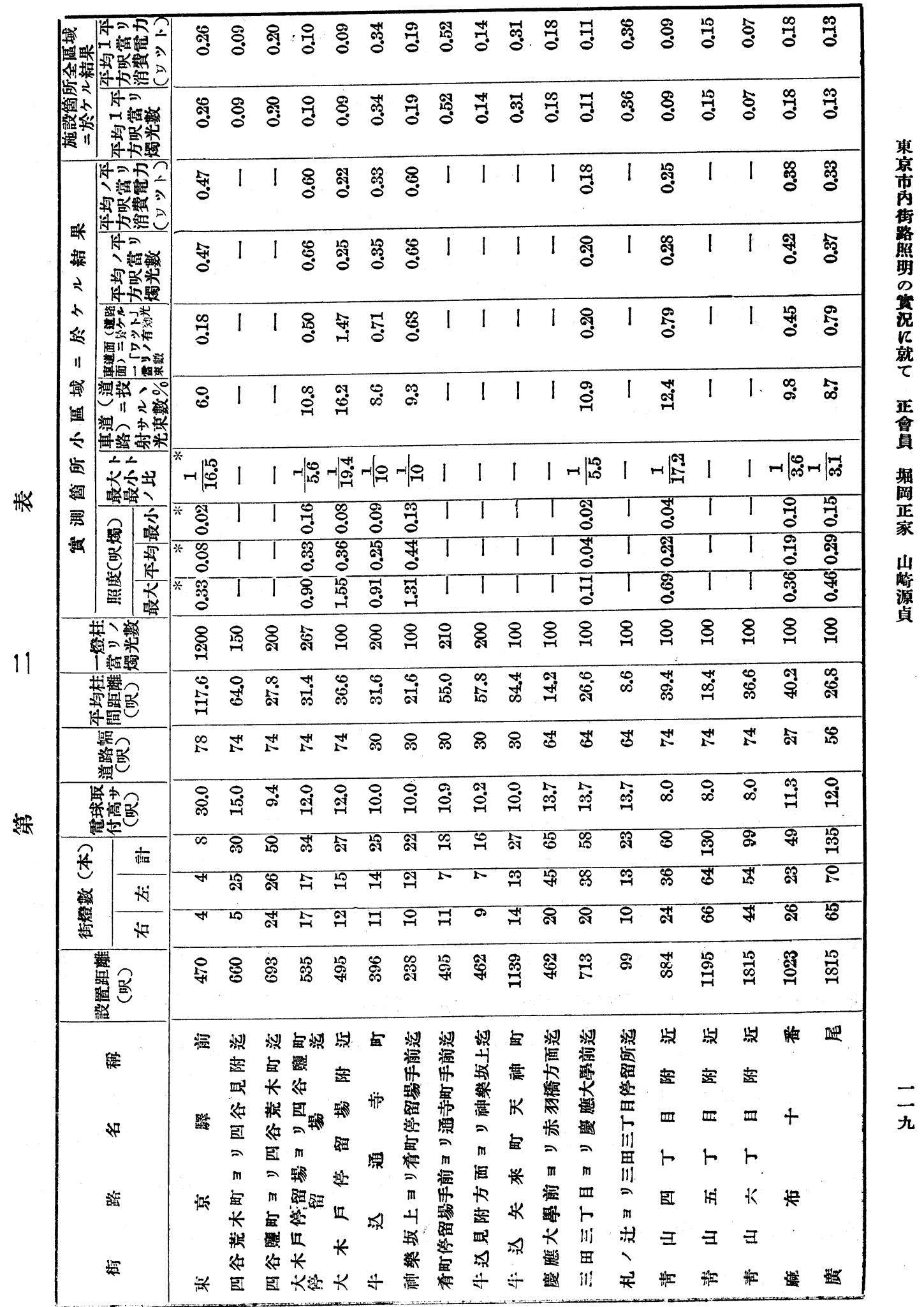


第 三 表

(計算 に上るも字)

\begin{tabular}{|c|c|c|c|c|c|c|c|}
\hline 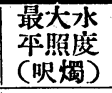 & \begin{tabular}{|l} 
最小水 \\
盟 \\
(吹喥)
\end{tabular} & $\begin{array}{l}\text { 最大卜 } \\
\text { 最小, } \\
\text { 比 }\end{array}$ & \multicolumn{5}{|c|}{ 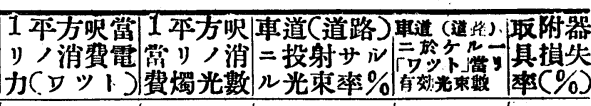 } \\
\hline 0.30 & 0.04 & $1 / 7.5$ & 0.41 & 0.41 & 8.08 & 0.24 & 73 \\
\hline 0.17 & 0.03 & $3 / 6.5$ & 0.53 & 0.53 & 3.94 & 0.12 & 81 \\
\hline 1.16 & 0.14 & $1 / 11.4$ & 0.66 & 0.00 & 10.8 & 0.50 & 58 \\
\hline 0.86 & 0.16 & $1 / 5.3$ & 0.25 & 0.22 & 16.0 & 1.45 & 不明 \\
\hline 1.87 & 0.19 & $1 / 9.8$ & 0.66 & 0.60 & 9.00 & 0.65 & $=$ \\
\hline 1.28 & 0.09 & $1 / 14$ & 0.36 & 0.33 & 8.63 & 0.71 & 19 \\
\hline 0.77 & 0.06 & $1 / 12.8$ & 0.28 & 0.25 & 12.45 & 0.79 & 49 \\
\hline 0.32 & 0.12 & $1 / 2.7$ & 0.42 & 0.38 & 9.82 & 0.45 & 55 \\
\hline 0.12 & 0.02 & $1 / 6.0$ & 0.20 & 0.18 & 10.85 & 0.20 & 84 \\
\hline 0.56 & 0.15 & $1 / 3.7$ & 0.37 & 0.33 & 8.68 & 0.79 & 15 \\
\hline \multicolumn{8}{|c|}{ 第 } \\
\hline \multicolumn{3}{|c|}{ 平均水平照明强度 } & \multicolumn{3}{|l|}{ 摘 } & \multicolumn{2}{|c|}{ 要 } \\
\hline \multicolumn{3}{|c|}{$0.5-1.0$ 呎㷎 } & \multicolumn{5}{|c|}{ 建物面に充分の光力當る事 } \\
\hline \multicolumn{3}{|c|}{$0.1-0.2=$} & \multicolumn{3}{|c|}{ " } & & \\
\hline \multicolumn{3}{|c|}{$0.05-0.1=$} & \multicolumn{5}{|c|}{ 建物面に僅少光の當る事 } \\
\hline \multicolumn{3}{|c|}{$0.02-0.04=$} & \multicolumn{5}{|c|}{ 光束全部を路面に投ずる事 } \\
\hline \multicolumn{3}{|c|}{$0.005-0.02=$} & \multicolumn{5}{|c|}{ 僅かの光が家屋面に虽る事 } \\
\hline
\end{tabular}

(P. S. Millar)

明に要せらる本均水本照明强度の標準として P.S. Millar 氏に依らて發表せら れれる物を示せば第四表の如く吾人の測定せる筒所の大部分は本表に於ける二流商 業街路以上に相當す次に普通計算に依り求さる照度曲線が賽測の8のと如何程の差 違あるか及取付器具に依る損失幾分なるかる見んが爲に計算及實測による本均水本 照度を等しくする樣に取付器具の損失率を定めれり。斯の如くにして求めれる損失 率は第三表の最後の闌に示す如くにして 甚だ高く、殊に三田通の如さは80\%以上 の損失を示せり。此の損失は器具による損失が大部分なる外、電球の能率を新し 〕時と同一に探りてるによる。然も器具の新しす時は第五表 (一)(二)に示す如く 器具のみによる損失は比較的少く乳白色の外球にては $8-29 \%$ 範图なるが故にか かる過大損失を生じれるは主に器具並に電球の杯埃附着に基くるのなるべし。 八、街燈設置方法

街登器具取付の方法は下記の如く三種に大别せらる。 


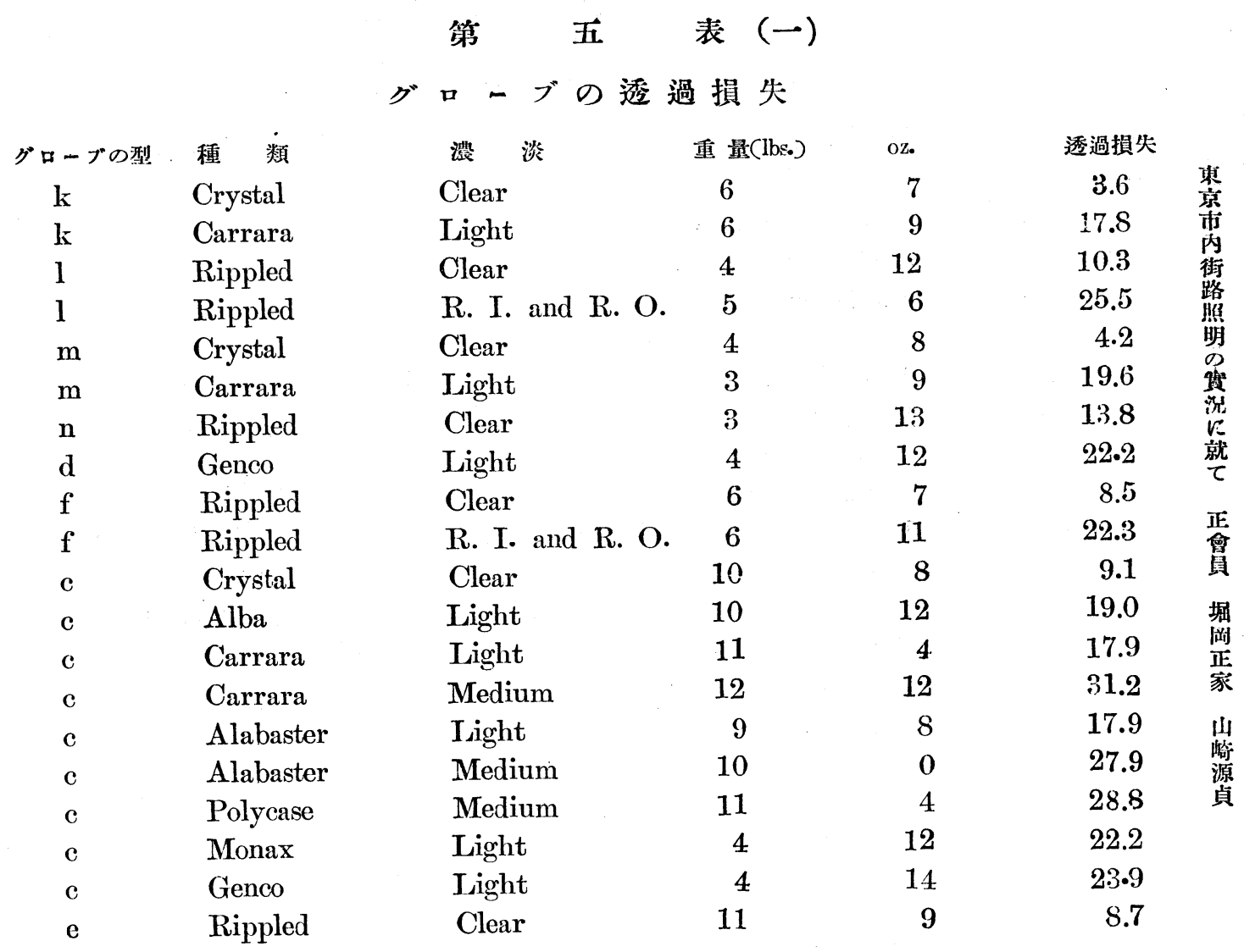

1. 支持線にて街路の中央に釣す方法

2.ブラッケット式としなし電柱又は建物壁面に取付くる方法

3. 登柱を立つる方法

第一の方法は比較的有效にて歐米にて可成り探用せられて居るふ僼裁等が良くせ ず我國では餘り探用して居らず實測箇所中に於ても三田及龁谷の小道に約二丁程に 亘り施設せられれる物を見受れるのみにて組織的に施設せられれるを見受けず。

第二の方法は一般に經濟的なる方法にして殊に道幅の犷く群集の雔沓する所には.

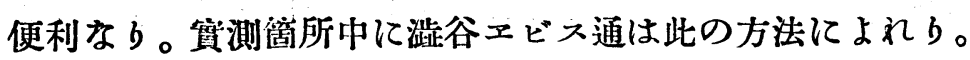

第三の方法は所謂る White-way lightingの方法にて特に登用の柱を立て此の上に 多燈式、一登式、向上式、吊垂式其他の器具を取付けるものにして實測简所の大蔀 分は下記の方式による。

多燈吊垂式東京䁺前 四谷監町停留場附近 牛込种樂坂下 通寺町 
第五表（二）

附屬器具による損失表

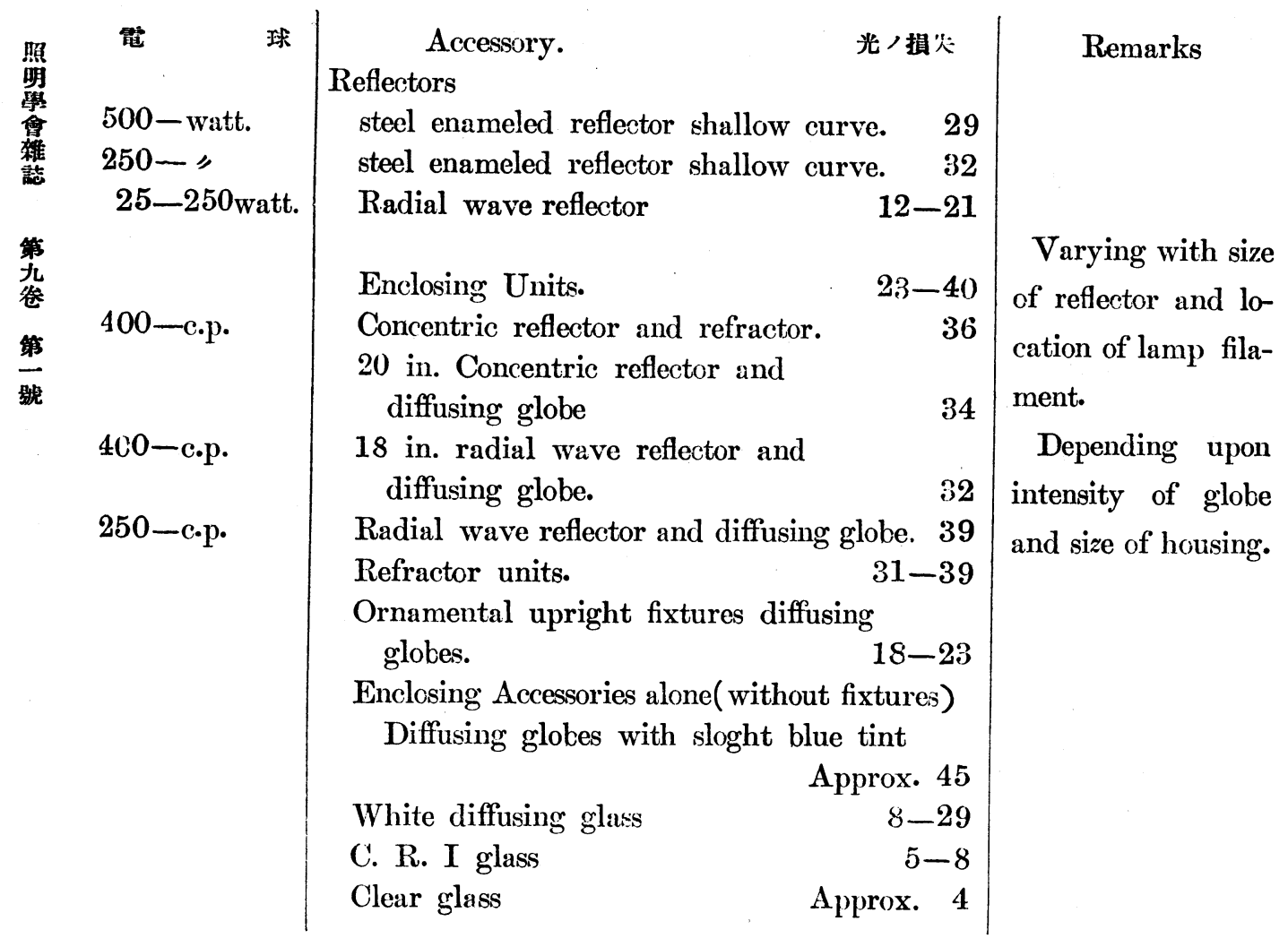

一燈吊垂式四谷暞町三丁目 清山四丁目 麻布十番

一燈问上式 三田通

又燈柱の配列方法多大别

a. 道路の兩㑡車道と步道との境に相賗して樹つる方法

b. 道路の兩側車道と步道との間に千鳥形に澍つる方法

の二方法あれども東京沞の現狀に在りては多くは商業組合等にて其の組合區域を

限 りて設置せられ、組織的の照明設備の施されれる處が㱠んど無しと云ふも過言に あらず、從て多くは店舖の前又は店舖との間等に設けられて、上記の如さ組織的の配 列方法に依つて樹てられてる物は䐝測の範園には噘密なる意味に於ては絕無にし て a, b を混用せるが如さ不規則的次るもののみな。

ニ、登柱の間隔と器具取付の高さ 

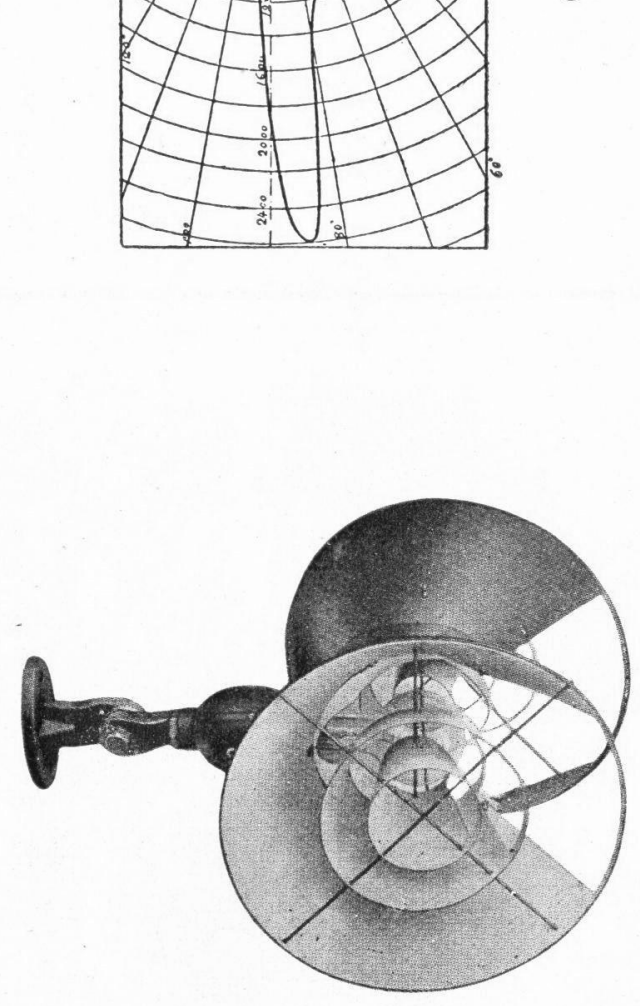
一定の大さの電球、一一定の配光特性の器具を用ふれば所要照度所要均一度により 登柱の間隔及取付器具の高さは定むる。

東京市內の質測は大略下の如く詳細は第一乃至四圖、第七乃至十圖及び第十四圖 に於て明なる。

電球の大さ

10 ワット乃至 100 ワット（東京驛前を除く）

燈柱間隔

10 呎的至 120 呎

取付器具の高さ 8 呎乃至 15 呎（東京驛前を除く）

ホ、使用光源並に街路器具の種類及び其の他の配光

實測範圍に於て 使用せられれる光源は虎斯封入電球及び普通のタングスラン電 球のみなり。其の燭力に於ては大部分 100 ワット以下の小電球な b。

第 一 一 圖

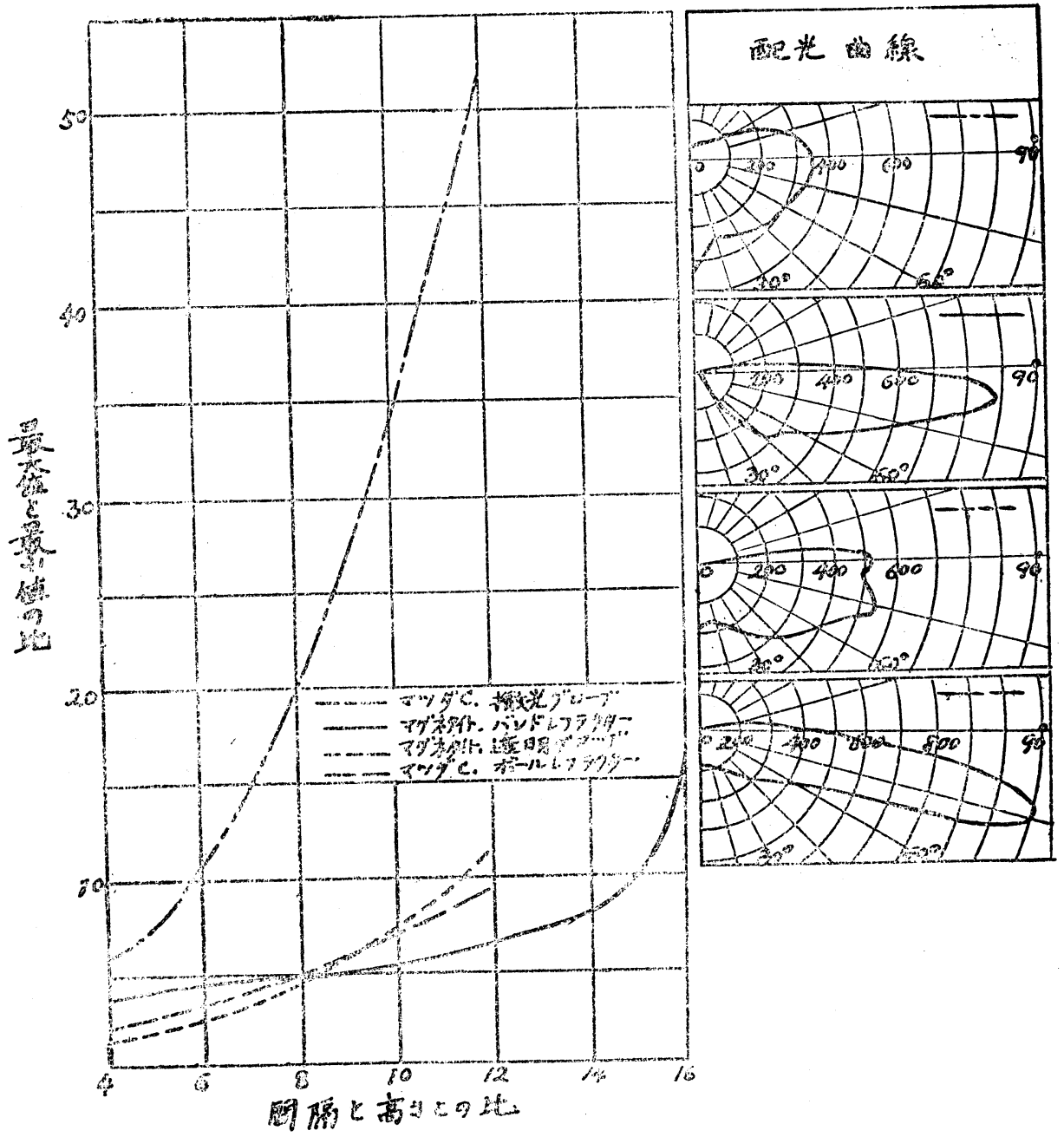

引 
資測管所に於以る電燈附屬器具第一圖に示寸第悬圖及び第二圖乃至第四圆（筫測

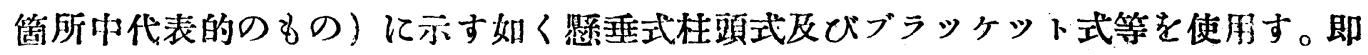

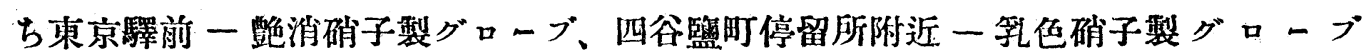
四谷覧町三丁目附近一斑瑯引金物製セード、神樂坂一孚他グローブ、牛込通寺町一珐

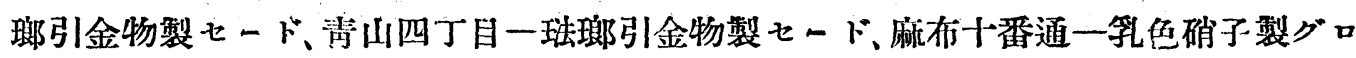
ーブ、三田通一乳色硝子製グローブ、下澁谷メビス通一珐唧引金物製セート、にて

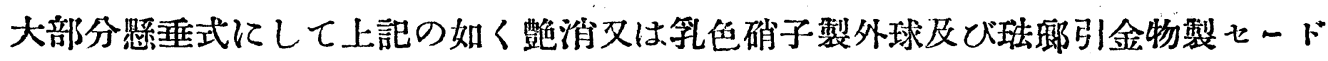
等を使用す。街路照明用特に設計せられそる椾な器具はなし第十一圖は死斯入電球 とマグネタイト弧光登に付さレフレクターを使用せる時と你用せさる時との此敕を 示す物にしてレフレクターを便用する和によb配光を適冨とし均一度か浪好になる てとを示するのなり。現在の東京古に就て見るに道路の幅は多くは八十尺以下のる の殊に 30 呎乃至 60 呎位の道路が多く、染京䮨前又は日比谷の大通の如 道幅を有 する所殆どなし故に現在では届光器の如さを使用する事の必要ある街路は少なし （但し新都市完成の曉には大通には屈光器の如与器具を利用して光源の配光を適當 に調節なし光を有效に使用して能率良さ街路照明を施さざる可からす。郊外等の自

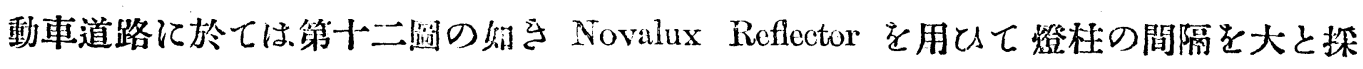

第 一 三 圆

札ノ辻より三田三丁口市電停留場まご

震災正後

琴

柆

三
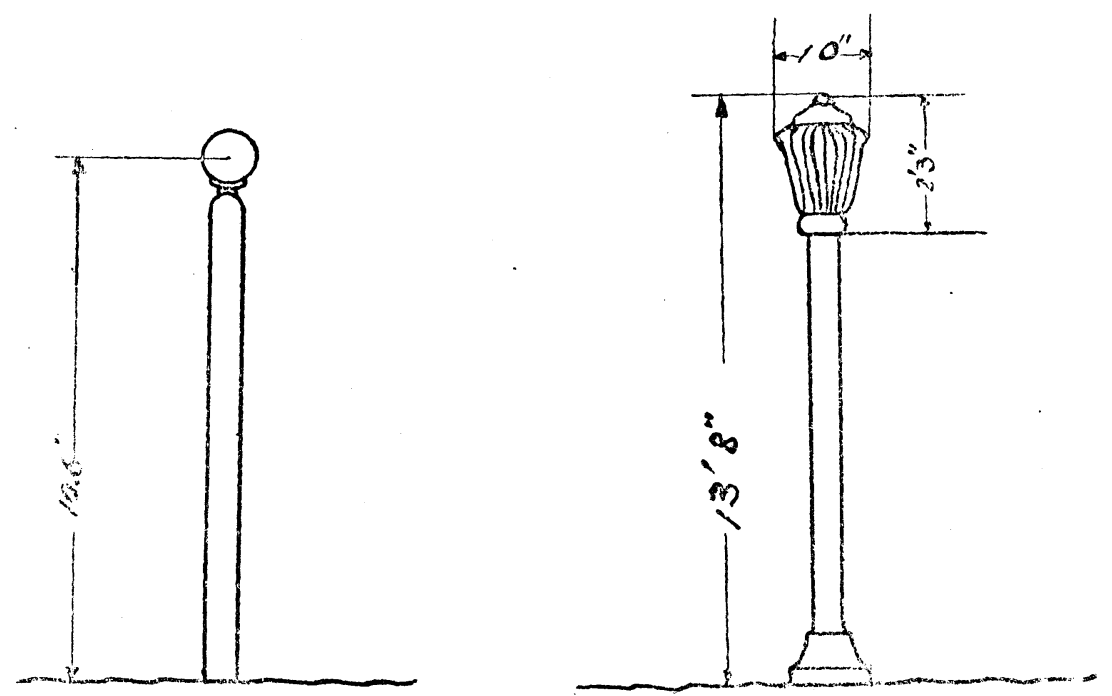


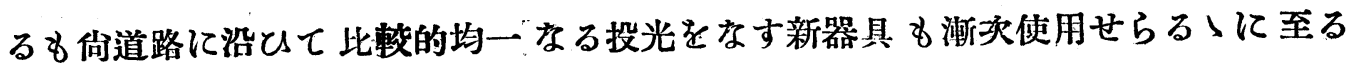
ペし。(最近鐵道省新宿驛附近の鐵道線路に使用され居る)

\section{四、霹災直後より最近に至る東京市街路照明に就いて}

震炎直後に於りる街路照明設備は下町方面の設備が、震災の爲め燒失され居る關 係、山の手方面に殘る設備が我が東京市に於ける街路照明設備の大部分なり己。其 の後山の手方面に於ける街路照明の新設せられれるるの可なり多く、貸測個所中に 於ても改善せられれるるの二、三あり（第十三圖參照代表的のもの）

第六表は東京市內に施され居る共同街路燈の統計表にして東電と市電との供給別 にして作りてる物なる。本表にて明なる如く震筑にて燒失せる下町方面る殆ど街路 登は復活せ b。然し第十四圖に示す如く 100 燭光以上の電球は甚だ少くして 100 燭 光以下の電球數約二分の一な b。東京市に於ては震然前よb非常に街路照明も進步

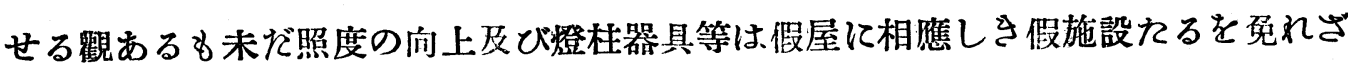
るもの大部分な b。

\section{五、內外に於ける代表的街路照明と現在に於ける東京市の街路照明}

第七表に示しれるは內外に於て 組織的に設備 せられれる代表的の街路照明設備 の實例な

光源には Long life arc lamp 又は高燭光瓦斯封入電球を使用し居る從て照度る 我國に此して非常に明く殆ど Super white way lighting の部に屬するものが多し。

我國代表的街路照明設備を見るに使用燈柱及取付器具等は諸外國の設備に比し て左程優劣なさにあらねどす照度が一般に低し。

東京市に就て 見るに第二表に示す如くにして銀座通を除く外に組織的なるすの 殆どなし。又燈柱として鐵柱を使用せる個所は數䇢所にして大部分は木柱にペンキ 染を施しれるものなる。使用器具る主として 10 吋乃至 15 吋位の珐璂引金物製 $\mathrm{p} セ$ ード及び乳色硝子製グローブなる。唯震災後東京市に於て橋上又は或る一部の廣場 又は道路に設置されつつある街燈設備は鐵柱に Alabastar glass 弊の Globe を取付 れるものある。(第十五圖參照) 實測箇所に於ても新に改善せられれる三田通りは第 十三圖に示す如く鐵柱にアルバスター硝子製グローブを取付てる設借走使用し居る 光源に使用されて居万電球の大さは第六表に示す如く現在では大部分100 watt 以下 


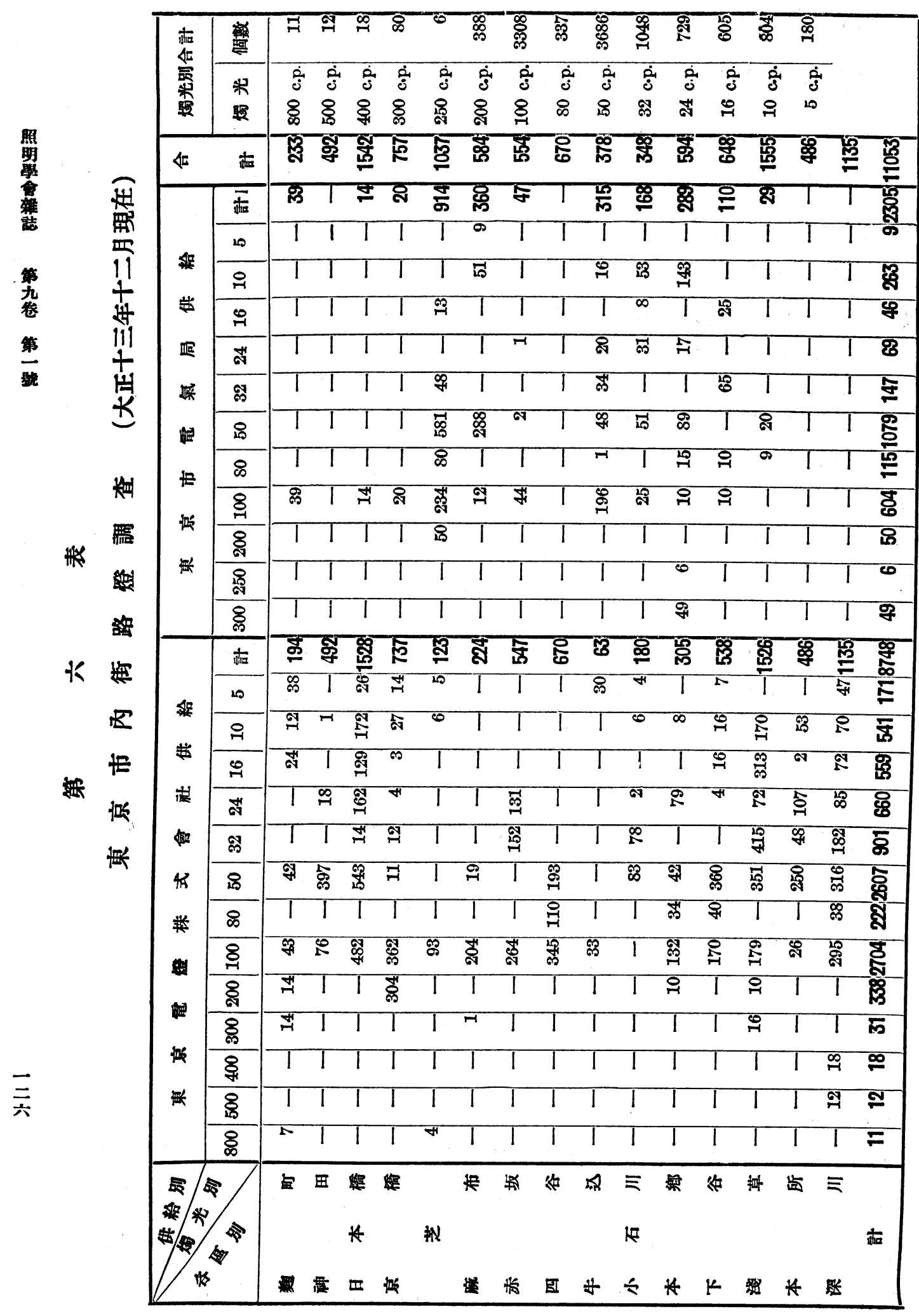


第十四圖

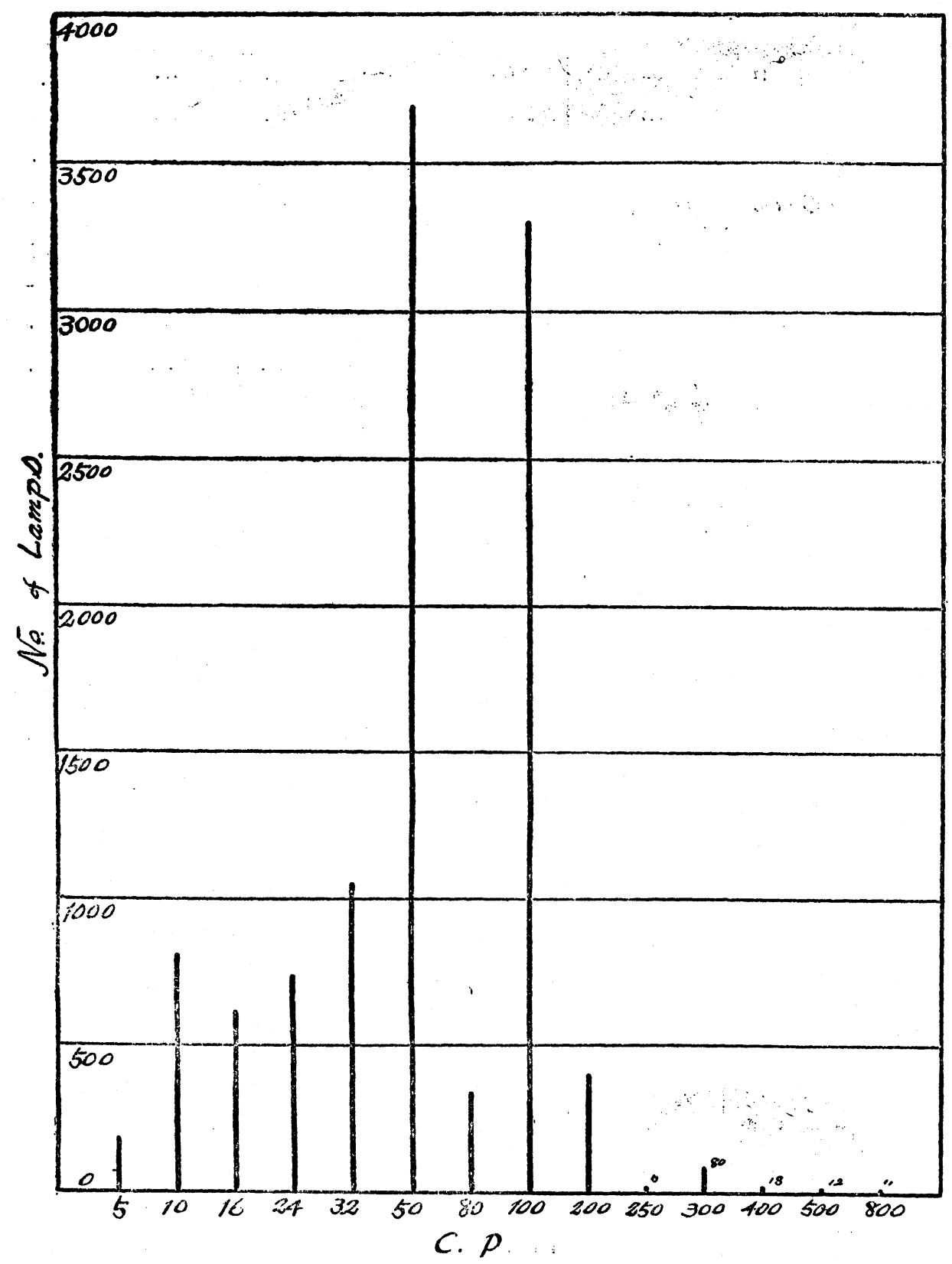

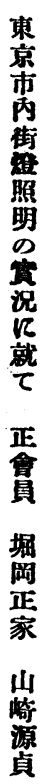

$\bar{z}$ 


\begin{tabular}{|c|c|c|c|c|c|c|}
\hline 街路 名 稱 & $\begin{array}{c}\text { 道 路の幅 員 } \\
\text { (呎) }\end{array}$ & 街 燈) & $\begin{array}{l}\text { 設 置 距 離 } \\
\text { (吹) }\end{array}$ & $\mid \begin{array}{l}\text { 地表上 } \\
\text { の高さ } \\
\text { (呎) }\end{array}$ & 配 列方 式 & 取付方法 \\
\hline 銀座通 リ京橋新橋間 & 90 & 147 & 3435 & 一 & 一 & - \\
\hline $\begin{array}{l}\text { 尾張町一丁目電車交叉點 } \\
\text { 附近 }\end{array}$ & 一 & 一 & - & - & - & - \\
\hline 尾 娠 町 二 丁 目 & - & - & - & - & - & - \\
\hline 同 & - & - & - & - & - & - \\
\hline 東京市三菱銀 行 前 & $\begin{array}{c}\text { (本均步道幅員) } \\
25\end{array}$ & 12 & $\begin{array}{l}\text { 本面步道の長 } \\
210.5\end{array}$ & - & - & $\therefore-$ \\
\hline 北海:道函館市末廣町 & $72\left(\begin{array}{c}\text { 車道 } \\
48\end{array}\right)$ & 62 & - & - & - & - \\
\hline 同 & 一 & - & - & - & 一 & - \\
\hline 同 & 一 & - & - & - & - & - \\
\hline 函館市惠比 須 町 電 車道 & 48 & 20 & - & 53.6 & - & - \\
\hline 同 & - & - & 一 & - & - & - \\
\hline 名古屋榮町通 リ & 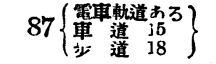 & 70 & 2473 & 一 & 一 & - \\
\hline 同 & - & - & - & 一 & - & - \\
\hline $\begin{array}{l}\text { Pitts burgh, Pa. Fifth } \\
\text { Avenue. }\end{array}$ & 36 & 50 & 一 & 18 & 事道二對稱 & $\begin{array}{l}ト ロ y ー \text { 桂k } \\
\text { ゲラッタートト }\end{array}$ \\
\hline $\begin{array}{l}\text { Pitts burgh, Pa. Federal } \\
\text { street. }\end{array}$ & 47 & 90 & - & 24 & 同上干鳥形 & 裝 飾 杜 \\
\hline $\begin{array}{l}\text { Chicago, Illinois Dear- } \\
\text { born Street. }\end{array}$ & 42 & 102 & - & 25 & 同上干鳥形 & 同 \\
\hline $\begin{array}{l}\text { Rochester, N. Y. Main } \\
\text { Street. }\end{array}$ & 80 & 222 & - & 14.5 & 同上對稱 & 同 \\
\hline $\begin{array}{l}\text { Hortford Conn. Main } \\
\text { Street. }\end{array}$ & $\begin{array}{l}90 \mathrm{ft} \text {. bet bldg } \\
\text { lines. }\end{array}$ & (twin ${ }^{\text {粎 } 82}$ & - & 14 & 車道側=干鳥 鳥形 & 同 $\underset{\text { (twin lamp) }}{\text { 上 }}$ \\
\hline $\begin{array}{l}\text { Washington, D. C. } \\
\text { Pennsyrvania, Av. }\end{array}$ & 109 & 123 & - & 15 & 同上干鳥形 & 裝 飾 柱 \\
\hline $\begin{array}{l}\text { New York, N. Y. Fifth } \\
\text { Avenue. ( } 25 \text { to } 58 \text { sts.) }\end{array}$ & 60 & (2) per post) & 一 & 19 & 同上干鳥形 & 同 $\quad$ 上 \\
\hline $\begin{array}{l}\text { Corning, N. Y. Market } \\
\text { Street. }\end{array}$ & 一 & - & - & 13.5 & 同上對 稱 & 裝 飾 桂 \\
\hline $\begin{array}{l}\text { Rochester, N. Y. Lake } \\
\text { Avenue. }\end{array}$ & 50 & 56 & 一 & 17.5 & 同 上干鳥形 & 同 \\
\hline $\begin{array}{l}\text { Milwaukee, Wis. Grand } \\
\text { Avenue. }\end{array}$ & 92 & - & 一 & 19.8 & 同上對 稱 & $\begin{array}{l}\text { トロリー桂に } \\
\text { ブラックット }\end{array}$ \\
\hline $\begin{array}{l}\text { New York, N Y. Seven- } \\
\text { th Ave. (110 to. } 136 \text { sts.) }\end{array}$ & 80 & 79 & 一 & 22 & 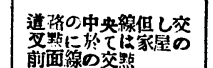 & 裝 飾 柱 \\
\hline $\begin{array}{c}\text { Chicago Illinois Troy } \\
\text { Street. }\end{array}$ & 35 & - & - & 22 & 車道片側のみ & 同 \\
\hline $\begin{array}{l}\text { Washington, D. C. Six- } \\
\text { teenth Street. }\end{array}$ & $\begin{array}{l}50 \mathrm{ft} \text {. (l60ft. bet } \\
\text { bldg lines) }\end{array}$ & 246 & 一 & 10.3 & 車道側に干鳥形 & - \\
\hline 桑港マーケット街 & - & 137 & 一 & 32 & 一 & - \\
\hline ロスアンゼルス市廣小路 & - & 134 & - & 27 & - & - \\
\hline $\begin{array}{l}\text { ニューョーク市サラトス } \\
\text { プ ング廣小路 }\end{array}$ & - & 70 & 5280 & 一 & 一 & 一 \\
\hline ロンドン市チーブサイド & 一 & - & - & - & - & - \\
\hline ロンドン市リヂエント街 & - & - & - & 21.5 & - & - \\
\hline 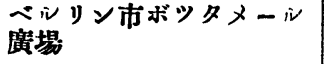 & - & 2 & - & 59 & 一 & - \\
\hline
\end{tabular}




\begin{tabular}{|c|c|c|c|c|c|c|c|c|}
\hline \multirow{2}{*}{$\mid$\begin{tabular}{|c|} 
平均桂 \\
問1距離 \\
(吹)
\end{tabular}} & \multirow{2}{*}{$\frac{\text { 照 }}{\text { 最高 }}$} & \multicolumn{2}{|c|}{ 度(吹罚) } & \multirow{2}{*}{\begin{tabular}{|l|} 
最高 \\
最低 \\
\end{tabular}} & \multirow{2}{*}{ 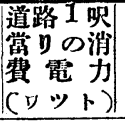 } & \multirow{2}{*}{ 光 } & \multirow{2}{*}{ 器 } & \multirow{2}{*}{ 備 } \\
\hline & & |本均| & 最低 & & & & & \\
\hline 46.5 & - & - & - & - & 一 & 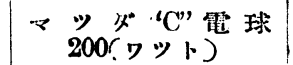 & - & \begin{tabular}{|l} 
大正11年 1 月 $29 \mathrm{f}$ \\
测定
\end{tabular} \\
\hline 69.0 & 2.55 & 0.483 & 30.085 & 30 & 11.6 & - & - & 古正11年 3 月15日 \\
\hline- & 0.46 & 0.240 & 0.06 & 7.7 & - & $"$ & - & 菄道 \\
\hline - & 1.67 & 0.780 & $\begin{array}{ll}0.09 \\
0.09\end{array}$ & 18.6 & 17.7 & $"$ & - & 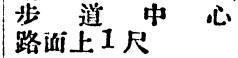 \\
\hline - & 0.42 & 0.260 & 0.07 & 6.0 & 11.4 & $"$ & - & - \\
\hline 42.3 & 0.58 & 0.370 & 0.19 & 3.1 & 9.45 & $"$ & - & - \\
\hline - & 0.25 & 0.210 & 0.19 & 1.3 & - & $"$ & - & 本道中心 \\
\hline- & 0.58 & 0.45 & 0.32 & 1.8 & - & " & - & 步道中心 \\
\hline 36.0 & 0.25 & 0.20 & 0.17 & 1.5 & 7.5 & $"$ & - & 道路中心楾上 \\
\hline- & 0.77 & 0.45 & 0.23 & 3.3 & - & " & $-\cdot$ & 霞燈中を貫く一直 \\
\hline 70.0 & 0.59 & 0.34 & 0.08 & 7.4 & - & $\begin{array}{c}15 \text { ア ム ペア“C”雪球 } \\
400 \text { 燭光 }\end{array}$ & 一 & $\begin{array}{l}\text { Series liphting } \\
\text { 步道中心線上 }\end{array}$ \\
\hline - & 0.16 & 0.14 & 0.125 & 1.3 & - & - & - & 車道中心線上 \\
\hline 約 80.0 & $\begin{array}{l}\text { Super } \\
=\text { 疄 }\end{array}$ & $\begin{array}{l}\text { White } \\
\qquad \notin 1\end{array}$ & Way lig & ghting & - & 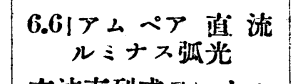 & アラバスクーグロープ & - \\
\hline 69.0 & & & & & - & 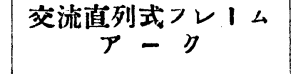 & アラパ グローブ & - \\
\hline 94.0 & & & 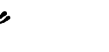 & & - & 同卡 & 同 & - \\
\hline 100.0 & & & 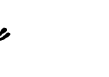 & & - & $\begin{array}{c}6.6 \text { アムペア、逆 形 } \\
\text { マグネタイト }\end{array}$ & アラバスクーグローブ & - \\
\hline 112,0 & & & 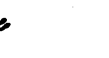 & & - & 600 㷎 光マッダ $\mathrm{C}$ & Novulux 1 號 型 & - \\
\hline 100.0 & & & $\Rightarrow$ & & - & 6.6 マムム゚ア逆 形 & 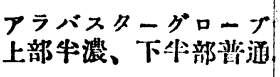 & - \\
\hline 100.0 & & & 6 & & 一 & $\begin{array}{c}120 \text { ヴオルト400ワット } \\
\text { マッ公 C }\end{array}$ & ライトカララグローブ & - \\
\hline 100.0 & & & 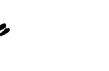 & & - & 400 燭 光 マッグ C & $\begin{array}{l}\text { C.R.1 型グロープ及 } \\
\text { 半透明矿子反射器 }\end{array}$ & - \\
\hline 460.0 & & " & e & & 一 & 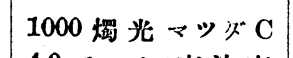 & アラバスターグローグ & - \\
\hline 92.9 & & $=$ & 6 & & - & 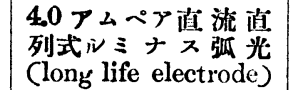 & ライトアラバスター & - \\
\hline 105.0 & & $=$ & 6 & & - & $\begin{array}{l}120 \text { ヴホルト400「レッ } \\
ト 」 マ マ ッ タ ゙ C\end{array}$ & $\begin{array}{c}\text { 通風を特殊にせる } \\
\text { カララグローブ }\end{array}$ & - \\
\hline 220.0 & & $=$ & & & - & 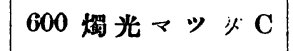 & アラバグローブ & 一 \\
\hline 120.0 & & 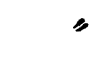 & & & - & $\begin{array}{l}5.5 \text { アム脜 列 } \\
\text { マッダC 約75 ッット }\end{array}$ & I6时アラバグローブ & 一 \\
\hline 110 & & " & 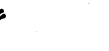 & & 一 & $\quad-$ & 一 & - \\
\hline 106 & & $=$ & & & 27.8 & ルミさテ弧光燈 & - & 3 䗳 \\
\hline- & & e & & & 19.2 & i ミテス弧光燈 & - & 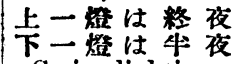 \\
\hline - & $\mathbf{2 . 0}$ & 1.23 & 0.72 & 2.8 & 一 & $\begin{array}{l}\text { P } \\
100 \text { C.P, } 250 \text { C.P. "C }\end{array}$ & 一 & $\begin{array}{l}\text { Series lighting } \\
\text { Duoflex unit } 2\end{array}$ \\
\hline 135 & - & 一 & 0.20 & - & - & 發㷪弧 光 燈 & 一 & 步道飞沿了 \\
\hline 148 & 7.6 & 1.0 & - & - & - & 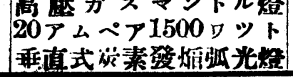 & 一 & 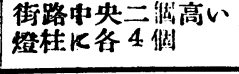 \\
\hline
\end{tabular}




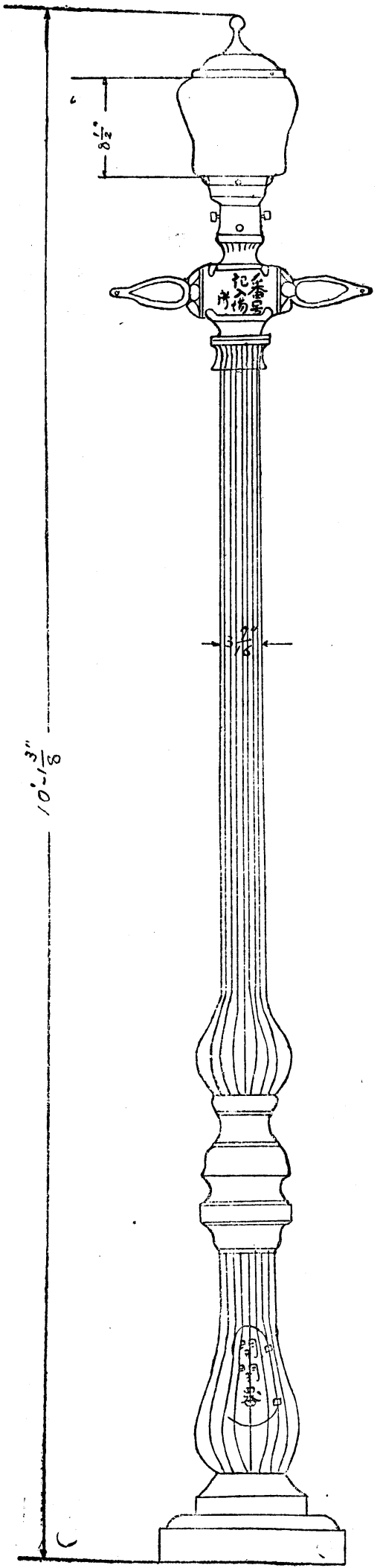

の囬空タングステン白熱電球を使用 して居る。然し最近は 100 watt-200 watts 位の死斯封入電球を使用され つ〉ある樣な狀態である。 六、結 論

1、本調查により東京市現在の 街路照明施設の詳細を明かにせり。 即斥均照度、均一度、燈基、器具の優 劣等は凡て明暸となれb。又塺埃多 马街路に於ける器具名興了る損失率 の大さをる磪めてb。

2、東京市內街路照明の照度、均一 度等にては譇外國に比するも大なる 棌色なし。但施設區域の狹小なるを 極めて組織的ならざる事。登基及附 屬器具の粗末にして一時的なる事等 は漱次改良せらるべさ事なる。

3、上記の如く組織的ならざる事 又設借の一時的なる事等の原因は施 設出資者が小なる組合等るるによ る、依つて完全なる設備をなさんに は市當局の如气大なる公共國體の手 に俟てざるべからず。

4. 街路照明の不完全なるによる 人命及財產上の損害に就ては其意外 に大なるものあるは交献 $(1)$ 及 $(2)$ 其 他に於て報知あ b。我國に於て子街 路照明施設の重要を世人に了解せし 
ひべく齐關係方面と協調して其統計的調查を行子事は甚だ必要なり。米國クリーブ ランド市に於ける調查に依れば交通事故の二割は街路照明の不足によるものとい ふ。東京市內に於ける交通事故も第十六圖の如く逐年塔加しつ〉あるなれば照明施 設の完借も遂年其の重要を增するのなる。

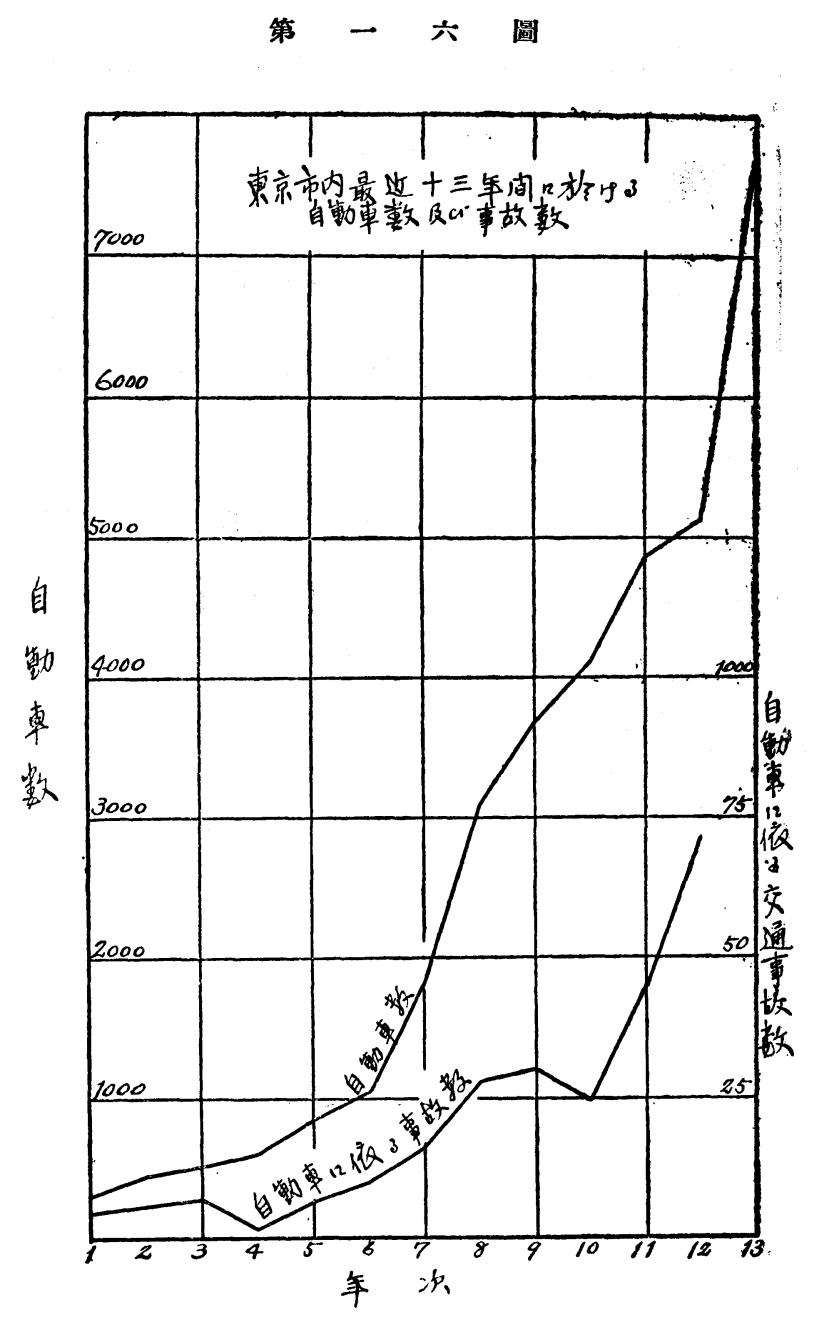

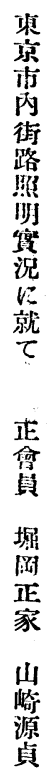

